\title{
THE DISPROPORTIONATE IMPACT THEORY OF RAGIAL DISCRIMINATION
}

\author{
Michael J. Perry $\dagger$
}

\section{TABLE OF CONTENTS}

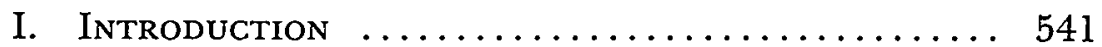

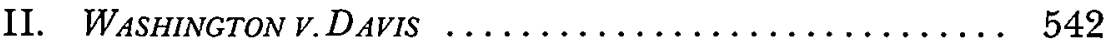

A. The Decision ................... 542

B. The Pre-Washington Confusion ........... 544

III. The Motivational Modes of Racial DiscrimiNATION ...................... 548

A. Rehearsing the Obvious: Race as a Criterion of Selection on the Face or in the Administration of a Law ..

B. " $X$ " as a Criterion of Selection Where " $X$ " Is the Functional Equivalent of Race ..............

IV. Beyond the Traditional Modes: Nonmotivational Racial Discrimination ............... A. " $X$ " as a Criterion of Selection Where " $X$ " Has a Disproportionate Racial Impact ..............

B. The Underlying Premises of Disproportionate Racial Impact Theory ......................

V. The Flexibility and - Contextually Limited Character of Disproportionate Racial Impact

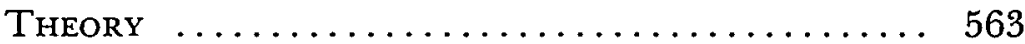

A. The Flexibility of DRI Theory .............. 563

B. Contexts in Which DRI Theory Is Not Applicable ... 566

1. Jury Selection ................. 566

2. Legislative Districting ............ 568

C. Contexts in Which DRI Theory Is Applicable ...... 571

1. Public Employment ............... 571

2. Administration of Public Schools ........ 574

3. Land Use Policy ............... 580

VI. Conclusion: A Question of Judicial Role ...... 586

$\dagger$ Assistant Professor of Law, The Ohio State University. A.B. 1968, Georgetown University; J.D. 1973, Columbia University. Member, New York Bar. 


\section{INTRODUCTION}

On June 7, 1976, the Supreme Court of the United States announced its decision in Washington $v$. Davis, ${ }^{1}$ and the implications of the Court's opinion are enormously consequential. The Court rejected a nonmotivational theory of racial $^{2}$ discrimination (which $I$ will refer to as the disproportionate racial impact theory, or simply DRI theory), holding that the equal protection clause of the fourteenth amendment prohibits only government action undertaken with a "discriminatory purpose." 1976 Term, the Supreme Court will again have occasion to consider the disproportionate impact theory of racial discrimination. The Court has agreed to review a ruling by the United States Court of Appeals for the Seventh Circuit striking down an exclusionary land use decision on the ground that the decision had the effect of reinforcing residential racial isolation. ${ }^{4}$ Thus, it it especially important that an effort be made to explicate disproportionate racial impact theory: the theory's underlying premises; the flexible standard of review contemplated by the theory; and the types of government action to which the theory,

196 S. Ct. 2040 (1976).

2 Throughout this Article reference is made to "racial" minorities and "racial" discrimination. "Race" has been attacked as a misleading and outmoded term. See Bakke v. Regents of the Univ. of Cal., Super. Ct. No. 31287, slip op. at 15-16 (Cal. Sup. Ct. Sept. 16, 1976). "Race" is used in this Article for want of a better term and because the issues addressed here have arisen primarily with reference to "race" as the term is conventionally understood. Perhaps disproportionate impact theory could be extended to non-"racial" groups. See note 100 infra \& accompanying text. Compare Anthony v. Massachusetts, 415 F. Supp. 485 (D. Mass. 1976) (veterans' preference invalidated because of disproportionate impact on women), with Branch v. DuBois, 418 F. Supp. 1128 (N.D. Ill. 1976) (veterans' preference upheld in face of disproportionate impact challenge). The immediate concern, however, is the core application of the theory. Therefore the discussion will proceed in terms of "race." Frequent reference will be made to blacks because the application of DRI theory to actions disproportionately affecting blacks serves as the paradigm for application to other minorities.

${ }^{3} 96 \mathrm{~S}$. Ct. at 2050 . A government action has a disproportionate racial impact if it has the effect of disadvantaging a greater percentage of nonwhites than whites, or of disadvantaging nonwhites much more grievously than whites. See note 4 infra. The term "disproportionate impact" is preferable to "discriminatory effect," because the latter has a pejorative connotation that tends to confuse two distinct issues: (1) whether an action has a disproportionate impact or effect, and (2) whether a disproportionate impact is justifiable. See Vulcan Soc'y of New York City Fire Dep't, Inc. v. Civil Serv. Comm'n, 490 F.2d 387, 391 n.4 (2d Cir. 1973).

${ }^{4}$ Metropolitan Hous. Dev. Corp. v. Village of Arlington Heights, 517 F.2d 409 (7th Cir.), cert. granted, 423 U.S. 1030 (1975); see notes 181-92 infra \& accompanying text. The court of appeals refused to disturb the district court's finding that the exclusionary decision was not motivated by a discriminatory purpose. Id. at 412 . An action reinforcing racial isolation is said to have a disproportionate racial impact, even though both whites and nonwhites are kept separate, because racial isolation constitutes a much greater disadvantage to the isolated minority than to the majority. 
if accepted, would apply. The point of departure for the discussion is Washington. My concern is less that the Court in Washington reached the result it did than that, in arriving at that result, it failed to address the crucial underlying issues.

\section{WASHINGTON V. DAVIS}

\section{A. The Decision}

In Washington $v$. Davis, two black men who had been denied positions as police officers with the Metropolitan Police Department of the District of Columbia because of their failure to perform satisfactorily on Test 21, a written examination used by the Department in selecting candidates for its Recruit School, claimed that the Department's use of the written examination violated their rights under the due process clause of the fifth amendment. ${ }^{5}$ Seeking declaratory and injunctive relief, they argued that use of the test was unconstitutional, because a greater proportion of blacks than whites failed to perform satisfactorily on it and because the test did not bear a demonstrable relation to job performance. The plaintiffs made no claim of intentional or purposeful racial discrimination. ${ }^{6}$

Test 21 was developed by the United States Civil Service Commission for general use throughout federal civil service as a measure of verbal ability. ${ }^{7}$ The test is not related specifically to

5 The plaintiffs, challenging federal action, relied on the equal protection component of the fifth amendment due process clause. See Bolling v. Sharpe, 347 U.S. 497 (1954). The plaintiffs based their case on 42 U.S.C. $\& 1981(1970)$ as well as on the fifth amendment. Davis v. Washington, 512 F.2d 956, 957-58 n.2 (D.C. Cir. 1975), rev'd, 96 S. Ct. 2040 (1976). Neither the district nor the circuit court discussed the relevance of $\$ 1981$ to the underlying complaint. Plaintiffs did not rely on Title VII of the Civil Rights Act of 1964, 42 U.S.C. $\$ \S 2000 \mathrm{e}-2000 \mathrm{e}-15$ (1970), as amended, 42 U.S.C. $\S \S 2000 \mathrm{e}-16$ to $2000 \mathrm{e}-17$ (Supp. V 1975), which was not applicable to government employment at the time the suit was commenced. At oral argument before the Supreme Court, defendants' counsel indicated that the applicability of Title VII to the instant case was problematic because plaintiffs had not satisfied its procedural requirements. 96 S. Ct. at 2047 n. 10.

The defendants pointed out to the district court that 5 U.S.C. § 3304(a)(1) (1970), which was not invoked by the plaintiffs, requires, in effect, that federal civil service examinations be job-related within the meaning of Title VII and Griggs v. Duke Power Co., 401 U.S. 424 (1971). 96 S. Ct. at 2052 n.15. The Supreme Court, in addition to rejecting plaintiffs' constitutional theory, held that Test 21 passed statutory muster under $\$ 3304(a)(1)$ and, by implication, under Title VII. The Court accepted the district court's conclusion that the job-relatedness requirement was satisfied by the positive relationship between performance on Test 21 and performance in the police training program. Id. at 2052-54.

${ }^{6} 96 \mathrm{~S}$. Ct. at 2045.

${ }^{7}$ A copy of Test 21 (Series No. 173, Feb. 1970) appears in the appendix to Judge Robb's dissenting opinion to the appeals court opinion. 512 F.2d at 967-76. 
police work, and the Metropolitan Police Department did not participate in development of the test. ${ }^{8}$ Between 1968 and 1971 , $57 \%$ of black applicants for positions with the Department failed Test 21 ; only $13 \%$ of white and other applicants failed. ${ }^{9}$ Reversing the district court's order that granted the defendants' motion for summary judgment, the court of appeals ruled that use of Test 21 was unconstitutional in that it had not been shown to bear a demonstrable relation to ability to perform on the job. ${ }^{10}$

The Supreme Court reversed, holding that the court of appeals had applied the wrong legal standard-a statutory standard applicable in Title VII ${ }^{11}$ cases-in resolving the constitutional issue. ${ }^{12}$ Under Title VII a showing of disproportionate racial impact puts the burden on the employer to establish that the challenged hiring or promotion practice bears a demonstrable relation to job performance. ${ }^{13}$ A Title VII plaintiff need not claim intentional or purposeful discrimination. ${ }^{14}$ In Washington, the Supreme Court held that a showing of disproportionate impact is not sufficient to make out a constitutional claim of racial discrimination; a claimant must establish "discriminatory purpose."15 Absent such a showing, the government need establish only that the challenged action has a rational basis. ${ }^{16}$ The Court cited as authority cases involving constitutional claims of racial discrimination in jury selection, ${ }^{17}$ legislative districting, ${ }^{18}$ public

896 S. Ct. at 2045.

${ }^{9} 512$ F.2d at 958-59. Test 21 is administered throughout federal civil service. Between 1970 and 1971, outside the District of Columbia, the proportion of blacks failing Test 21 was $47 \%$, while the proportion of whites and others failing was only $12 \%$. Id. at 959 n. 10.

${ }^{10}$ The district court, in denying the plaintiffs' motion for summary judgment (which presented only the constitutional issue) and granting the defendants' motion for summary judgment (which disputed the constitutional claim and asserted compliance with all applicable statutory criteria), held it sufficient, for constitutional and statutory purposes, that Test 21 measured ability to pass written examinations administered during the training program. Davis v. Washington, 348 F. Supp. 15 (D.D.C. 1972). The Supreme Court sided with the district court with respect to the sufficiency, for statutory purposes, of training-program validation. $96 \mathrm{~S}$. Ct. at 2052-54.

1142 U.S.C. $\$ \S 2000 \mathrm{e}-2000 \mathrm{e}-15$ (1970), as amended, 42 U.S.C. $\S \S 2000 \mathrm{e}-16$ to 2000e-17 (Supp. V 1975).

${ }^{12}$ Justice White delivered the opinion of the Court. Justice Stewart, without opinion, joined that part of the Court's opinion addressing the constitutional issue. Justice Stevens joined the Court's opinion with a single exception noted in his concurring opinion. Justice Brennan, joined by Justice Marshall, dissented from the Court's opinion as to the statutory issues, but declined to address the constitutional issue.

${ }^{13}$ Griggs v. Duke Power Co., 401 U.S. 424 (1971).

${ }^{14} \mathrm{Id}$.

1596 S. Ct. at 2047.

${ }^{16} I d$. at 2051.

${ }^{17}$ See notes 123-31 infra \& accompanying text.

${ }^{18}$ See notes 132-42 infra \& accompanying text. 
school administration, ${ }^{19}$ and welfare policy, ${ }^{20}$ and sought to distinguish cases intimating a rule contrary to that announced in Washington. ${ }^{21}$

The Court barely proffered an argument to support its rejection of disproportionate impact theory of racial discrimination. Justice White, in addition to citing prior cases that he mistakenly thought were relevant to the issue at hand, ${ }^{22}$ observed that a disproportionate impact rule, if accepted, might have the effect of invalidating a wide range of legislative programs. ${ }^{23}$ The Court thought that "extension of the rule beyond those areas where it is already applicable by reason of statute, such as in the field of public employment, should await legislative prescription." ${ }^{24}$ That observation, coupled with the Court's concession, without discussion, that "there is another side to the issue," 25 was all that the Court said in rejecting the disproportionate racial impact theory of equal protection, a theory that had been endorsed in some form by eight circuits ${ }^{26}$ and had not even been challenged by the defendants in Washington. ${ }^{27}$ Surely an issue of such importance deserved considerably more attention than the Court gave it.

\section{B. The Pre-Washington Confusion}

Considerable uncertainty existed prior to Washington in regard to whether the principal element of a constitutional claim of racial discrimination was discriminatory purpose or simply discriminatory effect. ${ }^{28}$ In Gomillion $v$. Lightfoot, ${ }^{29}$ the Supreme Court struck down an Alabama statute changing the boundaries

${ }^{19}$ See notes 150-72 infra \& accompanying text.

${ }^{20}$ See notes 114-20 infra \& accompanying text.

${ }^{21}$ See notes 36-49 infra \& accompanying text.

${ }^{22}$ See notes 127-42 infra \& accompanying text.

${ }^{23} 96 \mathrm{~S}$. Ct. at 2051-52.

${ }^{24} I d$. at 2052.

${ }^{25} I d$. at 2050. The Court cited federal circuit and district court opinions accepting some variant of disproportionate racial impact theory. $I d$. at 2050 n.12.

${ }^{26}$ See cases cited notes 88-90 infra.

${ }^{27} \mathrm{See} 96 \mathrm{~S}$. Ct. at $2046-47 \&$ n.8. The defendants argued only that the requirement of job-relatedness had been met.

${ }^{28}$ Compare Note, Legislative Purpose and Federal Constitutional Adjudication, 83 HARv. L. REv. 1887 (1970) (assuming that a law is unconstitutional if it has a disproportionate racial impact and arguing that discriminatory purpose can be probative of disproportionate impact, on the theory that the purpose will generate the effect), with Ely, Legislative and Administrative Motivation in Constitutional Law, 79 YALE L.J. 1205, 1221 n.51 (1970) (disproportionate impact is evidence of racial motivation, which is the proper constitutional issue).

${ }^{29} 364$ U.S. 339 (1960). 
of the city of Tuskegee from a square to "a strangely irregular twenty-eight-sided figure . . . The essential inevitable effect of this redefinition of Tuskegee's boundaries is to remove from the city all save only four or five of its 400 Negro voters while not removing a single white voter or resident." ${ }^{30}$ Justice Frankfurter ruled that because of "this inevitable effect," 31 the statute, in violation of the fifteenth amendment, deprived the black voters of Tuskegee of their right to vote. Nowhere in the Court's opinion did Justice Frankfurther mention discriminatory purpose. ${ }^{32}$

Eight years later, in United States $v$. O'Brien, ${ }^{33}$ the Court fueled the purpose-effect confusion by declaring that in Gomillion, "the purpose of the legislation was irrelevant, because the inevitable effect-the 'necessary scope and operation' . . . abridged constitutional rights." 34 Gomillion, the O'Brien Court asserted, stands "not for the proposition that legislative motive is a proper basis for declaring a statute unconstitutional, but that the inevitable effect of a statute on its face may render it unconstitutional."35

In Palmer $v$. Thompson, ${ }^{36}$ one of two cases distinguished in Washington, ${ }^{37}$ the Court upheld an action by Jackson, Mississippi, closing the municipal swimming pools. The city had been ordered to desegregate its pools and chose instead to shut them down in order "to preserve peace and order and because the pools could not be operated economically on an integrated basis." ${ }^{38}$ Justice Black, for the majority, rejected the claim that the city's action violated the equal protection clause because it was racially motivated. The closing of the pools involved no racial classification, nor did it "[affect] blacks differently from whites." ${ }^{9}$ In response to the complainants' motive-based argument, Justice Black said:

It is true there is language is some of our cases interpreting the Fourteenth and Fifteenth Amendments which may suggest that the motive or purpose behind a

${ }^{30} I d$. at 341 (emphasis supplied).

${ }^{31} \mathrm{Id}$. at 342 .

${ }^{32}$ It is clear, however, that Justice Frankfurter was implicitly referring to discriminatory purpose. See notes 50-54 infra \& accompanying text.

33391 U.S. 367 (1968).

${ }^{34} I d$. at 385 (citation omitted).

${ }^{35} \mathrm{Id}$. at 384 .

${ }^{36} 403$ U.S. 217 (1971).

$3796 \mathrm{~S}$. Ct. at 2049-50.

${ }^{38} 403$ U.S. at 219.

${ }^{39} \mathrm{Id}$. at 225. 
law is relevant to its constitutionality. . . But the focus in those cases was on the actual effect of the enactments, not upon the motivation which led the States to behave as they did. $^{40}$

In Wright $v$. Council of Emporia, ${ }^{41}$ the second case distinguished in Washington, ${ }^{42}$ the Court invalidated the withdrawal by Emporia, Virginia from the surrounding county school system. Emporia had acted in response to a district court order directing the county system to discontinue its "freedom of choice" desegregation plan and to adopt a "pairing" plan. ${ }^{43}$ The Court found the "discriminatory effect" 44 of Emporia's withdrawal, making the desegregation of the county system more difficult, dispositive of the constitutional claim: "[W]e have focused upon the effect-not the purpose or motivation-of a school board's action in determining whether it is a permissible method of dismantling a dual system. The existence of a permissible purpose cannot sustain an action that has an impermissible effect." 45

The language of Gomillion, O'Brien, Palmer, and Wright suggests that the chief element of a constitutional claim of racial discrimination is discriminatory effect, not discriminatory purpose. Nonetheless, in Washington, the Court correctly perceived that no prior Supreme Court case had really been based on the proposition that discriminatory effect alone is sufficient to make out a constitutional claim of racial discrimination. In Wright, Emporia shared the county's affirmative duty to undo the consequences of past de jure segregation. Emporia's withdrawal contravened that affirmative duty by making more difficult the desegregation of the county school system. This affirmative duty devolved on Emporia only because of Emporia's prior complicity in maintaining the segregated county system. This complicity in "an independent constitutional violation," 46 and not discriminatory effect per se, was the predicate of the Court's order voiding Emporia's withdrawal from the county school system.

The city action upheld in Palmer was not based on a racial classification, nor did it have a disproportionate impact on

\footnotetext{
${ }^{40} I d$. (citations omitted).

41407 U.S. 451 (1972).

4296 S. Ct. at $2049-50$.

43407 U.S. at 455-56.

${ }^{44} I d$. at 461 .

${ }^{45}$ Id. at 462 .

${ }^{46} I d$. at 459 .
} 
blacks. The pools were closed to all, and the city was not covertly supporting "private" swimming clubs. ${ }^{47}$ Furthermore, the articulated objective of the closing was legitimate. The basis of the Court's opinion in Palmer was not absence of discriminatory effect, but the fact that the closing involved no racial classification and was rationally related to a legitimate objective. The Court declined to strike down an action that involved no racial classification and that was rationally related to a legitimate objective, merely because the motives of some who took the action might have been regrettable. ${ }^{48}$ The Court held, in effect, that whatever the actors' hidden motives, the absence of a racial classification and the presence of a rational relation to a legitimate objective precludes a finding of discriminatory purpose. ${ }^{49}$

In Gomillion, the Alabama legislature redefined the city limits of Tuskegee. The new boundaries excluded from old Tuskegee all except four or five black voters but not a single previous white voter. The only plausible function served by the irregular boundaries was racial selection for the purpose of disenfranchisement. Alabama "never suggested, either in [its] brief or in oral argument, any countervailing municipal function which [the boundaries were] designed to serve."50 Thus the boundaries were the functional equivalent of a racial criterion; the inference was inescapable that the boundaries were employed to serve the very function race would have served.

Justice Frankfurter recognized this. Although he was not speaking specifically in terms of discriminatory purpose his conclusion in that regard was unmistakable. He declared that "the legislation is solely concermed with segregating white and colored voters by fencing Negro citizens out of town so as to deprive them of their pre-existing municipal vote."51 In addition, he observed: "[T]he Alabama Legislature . . . has deprived the petitioners of the municipal franchise and consequent rights and to that end it has incidentally changed the city's boundaries. . . . [S]tate power [has been] used as an instrument for circumventing a federally protected right."52 The O'Brien Court's reading of Gomillion as

47403 U.S. at 222-23.

${ }^{48}$ But see Brest, Palmer v. Thompson: An Approach to the Problem of Unconstitutional Legislative Motive, 1971 SuP. Cr. Rev. 95 (criticizing Palmer, arguing that illicit motivation should be dispositive in certain circumstances).

${ }^{49}$ See generally Ely, supra note 28.

50364 U.S. 339 , 342 (1960).

${ }^{51} \mathrm{Id}$. at 341 (emphasis supplied).

${ }^{52}$ Id. at 347 (emphasis supplied). 
resting on discriminatory effect and not purpose ${ }^{53}$ is simply incorrect. The use of a veiled racial criterion, not the effect of the statute, was unconstitutional. ${ }^{54}$

To say that the Court in Washington correctly perceived the absence of any precedent among its cases for disproportionate racial impact theory is not to say that the Court was justified in rejecting the theory as curtly as it did. Precedents have never been regarded as the alpha and omega of constitutional decisionmaking. ${ }^{55}$ The Court, confronted possibly for the first time by an equal protection claim based solely on a nonmotivational theory of racial discrimination, ${ }^{56}$ tendered a response not commensurate with the importance and complexity of the issues.

\section{The Motivational Modes of Racial Discrimination}

The Washington Court noted that "[t]he central purpose of the Equal Protection Clause of the Fourteenth Amendment is the prevention of official conduct discriminating on the basis of race." 57 There is absolutely no doubt that the central concern of the equal protection clause is racial discrimination, ${ }^{58}$ but what constitutes "conduct discriminating on the basis of race," remains unclear. That phrase could encompass conduct having a disproportionate racial impact.

The Washington Court held that there is no discrimination within the meaning of the equal protection clause without "discriminatory purpose." 59 The "discriminatory purpose" terminology used in Washington and elsewhere, however, is misleading. The central prohibition of the equal protection clause is directed against the government's deliberate use of race as a criterion of selection. ${ }^{60}$ A law might employ a racial criterion of selection as a means to an objective, or purpose, having nothing to do with

\footnotetext{
${ }^{53}$ See notes 33-35 supra \& accompanying text.

54 The effect of a statute, however, can be crucial in establishing that a criterion of selection is the functional equivalent of race-that the criterion's only plausible function is racial selection-and, therefore, that a discriminatory purpose is present. See Ely, supra note 28 , at 1268 .

${ }^{55}$ See generally P. Brest, Processes of Constitutional Decisionmaking: Cases AND Materials 1118-29 (1975).

${ }^{56}$ The plaintiffs made no claim of intentional or purposeful racial discrimination; they relied solely on disproportionate impact. $96 \mathrm{~S}$. Ct. at 2045 .

${ }^{57} \mathrm{Id}$. at 2047.

${ }^{58}$ See, e.g., Strauder v. West Virginia, 100 U.S. 303, 307-08 (1880); SlaughterHouse Cases, 83 U.S. (16 Wall.) 36, 71-72 (1873).

${ }^{59}$ See note 2 supra \& accompanying text.

${ }^{60}$ See, e.g., Loving v. Virginia, 388 U.S. 1, 9 (1967).
} 
race. Such a law does not have a discriminatory purpose but, because it employs a racial criterion, is nonetheless subject to strict scrutiny. ${ }^{61}$ Or the racial criterion may be a means to a "benign" racial objective, in which case the "discriminatory" purpose is to benefit rather than to discriminate against the racial minority. ${ }^{62}$ Thus, "discriminatory purpose" refers to the deliberate use by government of race as a criterion of selection; if this use is to be sustained, it requires a compelling objective that cannot be achieved without the racial criterion.

The presumptive invalidity of race as an criterion of selection derives from the notion embodied in the fourteenth amendment that one should be judged not as a member of a particular racial group, but as an individual. The basis of this individualist ethic is not the absence of legislatively relevant differences among races. ${ }^{63}$ Instead, the basis is the intolerably great moral cost of permitting government to deal with individuals as members of particular racial groups. Historically, the use of race

${ }^{61}$ See Korematsu v. United States, 323 U.S. 214 (1944). The objective of the challenged wartime relocation order was not discrimination but military security. A racial criterion of selection was used to achieve that objective. The order was upheld because only the means, and not the purpose, was discriminatory. Id. at 216, 223.

62 The validity of racial classifications designed for remedial purposes remains unclear. A cogent argument has been made that even the use of race as a criterion of selection to achieve a "benign" objective should be deemed presumptively unconstitutional because the very use of the racial criterion encourages racialism. See Kaplan, Equal Justice in an Unequal World: Equality for the Negro-The Problem of Special Treatment, 61 Nw. U.L. Rev. 363, 379-80 (1966):

[A]ny legal classification by race weakens the government as an educative force. ... [A] statute specifically granting Negroes a benefit tends to undermine the principle we are working so hard to establish [that a person is entitled to be judged on his individual merit alone, that race is irrelevant to the worth of the individual]. Preference for Negroes can thus be expected to be a major factor in preventing the education we are trying to bring about through a host of other laws.

In Alevy v. Downstate Medical Center, 39 N.Y.2d 326, 384 N.Y.S.2d 82 (1976) (sustaining preferential admissions to medical school), the court stated:

Granting preferential treatment to some racial groups encourages polarization of the races. Likewise, such treatment perpetuates thinking in racial terms and tends to undermine the incentive among those in the discriminated group to strive to improve their lot. . . . Hence, preferential treatment programs involve perpetuating undesirable perceptions of race as criteria affecting State action ... and, therefore, should be subjected to more careful scrutiny than traditional standards of rationality ordinarily invoke.

$I d$. at $335-36,384$ N.Y.S.2d at 90 (citations omitted). Moreover, when the resources are scarce, a law favoring one racial group necessarily disfavors another. Thus "benignness" is surely relative. See, e.g., Bakke v. Regents of the Univ. of Cal., Super. Ct. No. 31287 (Cal. Sup. Ct. Sept. 16, 1976) (medical school's minority admission program violates fourteenth amendment); DeFunis v. Odegaard, 82 Wash. 2d 11, 507 P.2d 1169 (1973) (sustaining preferential admissions to law school), dismissed as moot, 416 U.S. 312 (1974). ${ }^{63}$ This individualist ethic does imply that there are few, if any, relevant differences. 
as a criterion of selection has been part of an effort by the majority race to disadvantage a minority race. ${ }^{64}$ Moreover, the use of race as a criterion of selection encourages racialism, the mental habit of thinking about and dealing with persons of races other than one's own, not as individuals, but as "blacks," "whites," and so forth. This habit of mind is the soil in which discriminatory practices grow.

\section{A. Rehearsing the Obvious: Race as a Criterion of Selection on the Face or in the Administration of a Law}

Of the various ways in which government might employ race as a criterion of selection, the most obvious is the drafting of racial criteria into the language of a statute or other rule. In Strauder $v$. West Virginia, ${ }^{65}$ the statute struck down by the Supreme Court provided that "[a]ll white male persons who are twenty-one years of age and who are citizens of this State shall be liable to serve as jurors." 66 The statutes struck down in Loving $v$. Virginia $^{67}$ and McLaughlin $v$. Florida, ${ }^{68}$ unlike the statute in Strauder, did not by their terms include or exclude a specific racial group, but the statutes' language nonetheless set forth a racial criterion of selection. In Loving, the statute forbade interracial marriage; in McLaughlin, the statute imposed a severer penalty for interracial cohabitation than for cohabitation with a member of one's own race.

In Hunter $v$. Erickson, ${ }^{69}$ the city charter provision invalidated by the Court, like the provisions in Loving and McLaughlin, did not refer to a particular racial group and thus was not racially specific. It did employ, however, a racial criterion. Under the charter provision, any city ordinance regulating real estate transactions "on the basis of race, color, religion, national origin, or ancestry must first be approved by a majority of the electors voting on the question at a regular or general election before such ordinance shall be effective." ${ }^{\prime 0}$ Thus, whether the racial criterion employed is racially specific, as in Strauder, or nonspecific, as in Loving, McLaughlin, and Hunter, the operative

\footnotetext{
${ }^{64}$ See, e.g., Loving v. Virginia, 388 U.S. 1 (1967).

${ }^{65} 100$ U.S. 303 (1880).

${ }^{66} I d$. at 305 .

${ }^{67} 388$ U.S. 1 (1967).

68379 U.S. 184 (1964).

69393 U.S. 385 (1969).

${ }^{70} \mathrm{Id}$. at 387 (emphasis supplied).
} 
constitutional rule remains the same: the deliberate use by government of race as a criterion of selection is presumptively unconstitutional. ${ }^{71}$

Even when the language of a provision is free of racial criteria, it is possible that government officials will use race as a criterion in administering the rule. In the classic case of Yick Wo v. Hopkins, ${ }^{72}$ a San Francisco ordinance required an individual who wished to operate a laundry in a structure other than a brick or stone building to obtain a permit from the Board of Supervisors. The Board had granted permits to operate laundries in wooden buildings to all but one of eighty nonChinese applicants but to none of about two hundred Chinese applicants. The Board gave no reason for this disparity, and the Supreme Court, reversing petitioners' convictions for violating the ordinance, concluded that no plausible reason existed "except hostility to the race and nationality to which the petitioners belong, and which in the eye of the law is not justified." ${ }^{33}$

\section{B. " $X$ " as a Criterion of Selection Where " $X$ " Is the Functional Equivalent of Race}

A shrewd agency of government, intent on discriminating against a racial minority, will not specify race as a criterion of selection in the terms of a law. It will employ instead some criterion that serves substantially the same function-racial selection.

Many laws have been invalidated because they employed a veiled racial criterion-an " $X$," the functional equivalent of race. Gomillion v. Lightfoot ${ }^{74}$ involved a prime example of this device. ${ }^{75}$

${ }^{71}$ For a brief discussion of the application of this rule to benign racial classifications, see note 62 supra. The use of a racially nonspecific criterion of selection is quite properly not exempt from the general rule against racial classifications. Such racial criteria, as Loving, McLaughlin, and Hunter amply demonstrate, have all the vices of the racially specific criterion struck down in Strauder. Typically, they serve to disadvantage directly a racial minority, as in Hunter, or to express white supremacist ideology, as in Loving and McLaughlin. Moreover, such criteria undermine the effort to establish colorblindness in our socio-political life. See note 62 \& text accompanying note 64 supra.

72118 U.S. 356 (1886).

${ }^{73} I d$. at 374 . Of course, establishing that officials are using race as a criterion of selection can present difficult evidentiary problems. Reliance on statistical data has become commonplace in efforts to establish use of a racial criterion in the administration of a written rule facially neutral with respect to race. See, e.g., Mayor of Philadelphia v. Educational Equality League, 415 U.S. 605, 620 (1974): "Statistical analyses have served and will continue to serve an important role as one indirect indicator of racial discrimination in access to service on governmental bodies, particularly where, as in the case of jury service, the duty to serve falls equally on all citizens."

74364 U.S. 339 (1960).

${ }^{75}$ See notes 50-54 supra \& accompanying text. 
In Guinn $v$. United States, ${ }^{76}$ the Supreme Court invalidated a "grandfather clause" provision of the Oklahoma Constitution requiring a literacy test of all prospective voters except those who had been qualified to vote on or before January 1, 1866 (prior to the adoption of the fifteenth amendment), and their lineal descendants. In Lane $v$. Wilson, ${ }^{77}$ the Court struck down an Oklahoma voter registration statute, enacted in response to Guinn, exempting those who had voted in the last general election prior to Guinn. The Court decried "sophisticated as well as simple-minded modes of discrimination." ${ }^{\prime 8}$ In Schnell v. Davis, ${ }^{79}$ the Court affirmed a district court judgment ${ }^{80}$ invalidating an Alabama constitutional amendment requiring all prospective voters to "understand and explain" any provision of the Federal Constitution. The only plausible function served by that extraordinary requirement, administered by local registrars, was the disenfranchisement of black voters. The campaign to ratify the amendment clearly indicated that this disenfranchisement was the sole purpose for the amendment. ${ }^{81}$ As the Court later remarked,

[A] literacy test may be unconstitutional on its face. In Davis v. Schnell, ... the test was the citizen's ability to "understand and explain" an article of the Federal Constitution. The legislative setting of that provision and the great discretion it vested in the registrar made clear that a literacy requirement was merely a device to make racial discrimination easy. ${ }^{82}$

76238 U.S. 347 (1915).

77307 U.S. 268 (1939).

${ }^{78} \mathrm{Id}$. at 275 .

${ }^{79} 336$ U.S. 933 (1949) (per curiam).

8081 F. Supp. 872 (S.D. Ala. 1949).

${ }^{81}$ See id. at 879 n.9, 880.

${ }^{82}$ Lassiter v. Northampton Bd. of Election, 360 U.S. 45, 53 (1959). The delegation of too much discretion to local registrars has been treated by the Court as the equivalent of racial selection. Louisiana v. United States, 380 U.S. 145 (1965).

An interesting early example of the functional equivalence rationale is found in the lower federal court case of Ho Ah Kow v. Nunan, 12 F. Cas. 252 (C.C.D. Cal. 1879) (No. 6546), which involved a San Francisco ordinance requiring every male imprisoned in the county jail to have his hair "cut or clipped to a uniform length of one inch from the scalp thereof." Id. at 253. Plaintiff had defaulted on a fine imposed for a housing code violation and was imprisoned and shorn of his braided queue, the deprivation of which was regarded by certain Chinese persons at the time as a mark of disgrace. In sustaining plaintiff's action against the sheriff for damages, the circuit court reasoned that the only conceivable function served by the ordinance was discrimination against the Chinese:

The cutting off the hair of every male person within an inch of his scalp, on his arrival at the jail, was not intended and cannot be maintained as a 
Whether or not a criterion of selection, "X," is the functional equivalent of race, then, depends on whether or not " $X$ " plausibly serves some function other than racial selection. Certainly, the answer is not always clear. ${ }^{83}$ If a criterion plausibly serves no function other than racial selection, then the criterion is the functional equivalent of race, and its use necessitates the conclusion that government has employed a veiled racial criterion. The equal protection clause clearly forbids the deliberate use by government of race as a criterion of selection. This prohibition is not avoided merely because the racial criterion is covert.

\section{Beyond the Traditional Modes: Nonmotivational Racial Discrimination}

\section{A. " $X$ " as a Criterion of Selection Where " $X$ " Has a Disproportionate Racial Impact}

Thus far the varieties of racial discrimination considered have involved a motivational element-an intent or purpose to

sanitary regulation. The act by itself has no tendency to promote discipline, and can only be a measure of health in exceptional cases. Had the ordinance contemplated a mere sanitary regulation it would have been limited to such cases and made applicable to females as well as to males, and to persons awaiting trial as well as to persons under conviction....

... It is special legislation on the part of the supervisors against a class of persons who, under the constitution and laws of the United States, are entitled to the equal protection of the laws. The ordinance was intended only for the Chinese in San Francisco. This was avowed by the supervisors on its passage, and was so understood by every one. The ordinance is known in the community as the "Queue Ordinance," being so designated from its purpose to reach the queues of the Chinese, and it is not enforced against any other persons. The reason advanced for its adoption, and now urged for its continuance, is, that only the dread of the loss of his queue will induce a Chinaman to pay his fine.

Id. at $254-55$.

If the charter provision struck down in Hunter v. Erickson, see notes 69-70 supra \& accompanying text, had not been phrased explicitly in terms of race, but instead had specified "fair housing legislation" as subject to the referendum gauntlet, $c f$. Reitman v. Mulkey, 387 U.S. 369 (1967) (proposition 14 provided that "[n]either the State nor any subdivision or agency thereof shall deny, limit or abridge, directly or indirectly, the right of any person, who is willing or desires to sell, lease or rent any part or all of his real property, to decline to sell, lease or rent such property to such person or persons as he, in his absolute discretion, chooses."), the functional equivalence rationale would have dictated the same result. The only plausible function of such a criterion of selection ("fair housing legislation" or the equivalent language in Reitman) is to burden the passage of legislation beneficial to racial and religious minorities and thereby to facilitate private discrimination.

${ }^{83}$ Courts occasionally have been unreasonably deferential to implausible claims that the criterion in issue served a function other than racial selection and discrimination. See Ely, supra note 28, at 1298. Compare Deerfield Park Dist. v. Progress Dev. Corp., 22 Ill. 2d 132, 174 N.E.2d 850 (1961), cert. denied, 372 U.S. 968 (1963), with Banks v. Perk, 341 F. Supp. 1175 (N.D. Ohio 1972), aff'd in part, rev'd in part, 473 F.2d 910 (6th Cir. 1973). 
use race as a criterion of selection. This element, when it is ascertainable at all, will appear in the terms of a law or will be inferrable from the administration or singular function of a law. The variety of discrimination that DRI theory subjects to closer scrutiny involves no such motivational element. ${ }^{84}$ DRI theory applies to government action when an intent or purpose to use a racial criterion of selection, even if present, is not inferrable from the administration or operation of a law and thus is not visible to the reviewing court.

Laws having a disproportionate racial impact differ fundamentally from laws employing a criterion of selection that is the functional equivalent of race. A criterion is the functional equivalent of race when its only plausible function is racial selection. DRI theory applies to those laws whose criteria of selection plausibly serve functions other than racial selection. For example, a written examination for public employment may serve the function of racial selection, but it also serves the function of selecting a more skilled work force. While the neighborhood criterion in student assignment decisions serves the function of racial selection, it also serves the function of securing the advantages thought to accompany neighborhood schools. ${ }^{85}$ Similarly, an affluent suburb's decision preventing the construction of low income housing, in addition to fencing most blacks out of the predominantly white enclave, secures the myriad advantages of low density living. ${ }^{86}$ When a criterion of selection plausibly serves at least two distinct functions, only one of which is racial selection and the others are conventionally regarded as legitimate, a court cannot fairly conclude that the criterion was used for the purpose of racial selection. ${ }^{87}$

DRI theory has been developed by the lower federal courts, principally in three sorts of cases: those challenging (1) racial imbalance in public schools, (2) hiring practices in public employment, and (3) exclusionary land use decisions. At least five federal circuit court have applied variants of DRI theory in overturning decisions by school boards that plainly served legitimate functions-chiefly maintenance of neighborhood schools-but

${ }^{84}$ For a discussion of school desegregation cases that use a motivational fiction equivalent to a nonmotivational impact analysis, see notes 165-72 infra \& accompanying text.

${ }^{85}$ See note 162 infra.

${ }^{86} C f$. Belle Terre v. Boraas, 416 U.S. 1 (1974) (upholding a zoning regulation limiting land use to one-family dwellings).

${ }^{87}$ See note 49 supra \& accompanying text. 
that had the effect of creating racially imbalanced schools. ${ }^{88}$ Prior to Washington v. Davis, at least four courts of appeals and a district court had applied DRI theory in striking down public employment hiring practices that served legitimate functions but that disqualified a greater percentage of nonwhite than white applicants. ${ }^{89}$ And at least three circuit courts have applied DRI theory in overturning decisions with respect to zoning and public housing that served legitimate functions but that reinforced residential racial isolation in the affected communities. ${ }^{90}$

\section{B. The Underlying Premises of Disproportionate Racial Impact Theory}

As noted earlier, the traditional prohibition of equal protection is directed at the deliberate use by government of race as a criterion of selection. The corresponding duty of the government is negative in character: to refrain from using race, absent compelling justification, as a criterion of selection. In this respect, the traditional prohibition of equal protection is narrower than the prohibition of the first amendment. Under the first amendment, a legislature not only must refrain from using speech, association, and religion as criteria of selection-that is, as bases for penalizing or rewarding individuals ${ }^{91}$ —but also must affirmatively accommodate first amendment interests by pursuing its objective through means that minimize adverse effects on

${ }^{88}$ See, e.g., United States v. Texas Educ. Agency, 532 F.2d 380 (5th Cir. 1976); United States v. School Dist. of Omaha, 521 F.2d 530 (8th Cir.), cert. denied, 423 U.S. 946 (1975); Hart v. Community School Bd. of Educ., 512 F.2d 37 (2d Cir. 1975); Morgan v. Kerrigan, 509 F.2d 580 (1st Cir. 1974), cert. denied, 421 U.S. 963 (1975); Oliver v. Michigan State Bd. of Educ., 508 F.2d 178 (6th Cir. 1974), cert. denied, 421 U.S. 963 (1975). But see Johnson v. San Francisco Unified School Dist., 500 F.2d 349 (9th Cir. 1974). For a discussion of these cases, see notes 165-72 infra \& accompanying text.

${ }^{89}$ See, e.g., Davis v. Washington, 512 F.2d 956 (D.C. Cir. 1975), rev'd, 96 S. Ct. 2040 (1976); Castro v. Beecher, 459 F.2d 725 (1st Cir. 1972); Chance v. Board of Examiners, 458 F.2d 1167 (2d Cir. 1972); Carter v. Gallagher, 452 F.2d 315 (8th Cir.), cert. denied, 406 U.S. 950 (1972); Harper v. Mayor of Baltimore, 359 F. Supp. 1187 (D. Md.), modified sub nom. Harper v. Kloster, 486 F.2d 1134 (4th Cir. 1973). But cf. Tyler v. Vickery, 517 F.2d 1089 (5th Cir. 1975), cert. denied, 96 S. Ct. 2660 (1976) (disproportionate failure of blacks to pass bar exam not sufficient to make out an equal protection claim).

${ }^{90}$ See, e.g., Metropolitan Hous. Dev. Corp. v. Village of Arlington Heights, 517 F.2d 409 (7th Cir.), cert. granted, 96 S. Ct. 560 (1975), discussed in notes 181-92 infra \& accompanying text; Crow v. Brown, 457 F.2d 788 (5th Cir. 1972); Kennedy Park Homes Ass'n v. City of Lackawanna, 436 F.2d 108 (2d Cir. 1970), cert. denied, 401 U.S. 1010 (1971); $c f$. Southern Alameda Spanish Speaking Organization v. City of Union City, 424 F.2d 291 (9th Cir. 1970) (disproportionate impact theory endorsed in dictum).

${ }_{91}$ See, e.g., Keyishian v. Board of Regents, 385 U.S. 589 (1967). 
those interests. ${ }^{92}$ Thus, under the first amendment, it is not sufficient that a legislature has refrained from using an illegitimate criterion of selection. The legislature must select and fine-tune laws to avoid unnecessary intrusion on first amendment interests. By contrast, under the traditional prohibition of equal protection, it is sufficient that the legislature has refrained from using race or its functional equivalent as a criterion of selection. The legislature, in the course of enacting "neutral" laws, need not affirmatively accommodate the interests of racial minorities.

Why is the first amendment the source of an affirmative as well as a negative obligation, and the equal protection clause, as traditionally conceived, the source of only a negative obligation? The first amendment protects values and interests believed indispensable to the democratic functioning of the political process. ${ }^{93}$ Government is charged with the duty, under the first amendment, of safeguarding those values and interests-and thus the democratic process-by acting solicitously toward them as well as by refraining from deliberately abridging them. The equal protection clause serves principally as a brake on the lamentable tendency of the majority race wilfully to oppress or exploit racial minorities, and in this regard it prohibits, absent compelling justification, the use of race as a criterion of selection. Traditionally, however, it has not been thought wrongunfortunate, perhaps, but not wrong-that an individual or group is incidentally burdened by a law serving the public good. ${ }^{94}$ Incidental burdens. have been thought the fair price everyone, black as well as white, must pay, at some time or other, for the societal advantages of laws. After all, virtually every piece of legislation is burdensome to somebody. Accordingly, with respect to racial discrimination equal protection doctrine has focused almost exclusively on wilfull oppression or exploitation of minorities by the majority. This focus is especially understandable in light of what historically has been this society's severest moral affliction, racial animus.

Under DRI theory a law is presumptively unconstitutional, even though it employs no racial criterion of selection, if it has a disproportionate racial impact. Correlatively, government has an

${ }^{92}$ See, e.g., Sherbert v. Verner, 374 U.S. 398 (1963).

${ }_{93}^{3}$ See, e.g., Bork, Neutral Principles and Some First Amendment Problems, 47 IND. L.J. 1, 20-35 (1971).

${ }^{94}$ Such a law, employing no racial criterion of selection and hence racially "neutral," need have only a rational basis. See Washington v. Davis, 96 S. Ct. 2040, 2051 (1976). 
obligation, an affirmative duty, to pursue its legitimate interests by means of laws selected and fine-tuned for the purpose of avoiding unnecessary intrusion on the interests of racial minorities. DRI theory thus moves beyond the traditional prohibition, the negative duty, of equal protection and imposes on government an affirmative obligation akin to its affirmative obligation under the first amendment.

As indicated above, ${ }^{95}$ a law employing no racial criterion of selection is constitutionally legitimate, according to traditional equal protection theory, if it has a rational basis. This legitimacy is premised on the notion that virtually every law disadvantages somebody; that, as long as a law does not rest on an invidious classification and has a rational basis, the consequent disadvantage is ethically inoffensive. But this premise has limited force. When the disadvantage is suffered not merely as a consequence of a law, but also and more fundamentally as a consequence of prior govermmental action that was constitutionally (and ethically) offensive, it cannot be maintained that the disadvantage is ethically inoffensive. The disadvantage, in such a circumstance, is the fruit of prior government misdeeds and, accordingly, should bear a heavier burden of justification than that required of a truly neutral disadvantage. But surely this is rather abstract. Consider the point in the context of disadvantage disproportionately visited on blacks by a racially neutral law.

The reason that some government actions disproportionately disadvantage blacks stems from the social position of blacks in American society. A greater proportion of blacks than whites are poor and poorly educated. Blacks not only have been discriminated against in education, ${ }^{96}$ but, because familial and social disintegration resulting from two centuries of slavery and discrimination have impeded the motivation and cognitive development of many black children, many blacks also have been unable to take optimal advantage of the inferior educations offered them. ${ }^{97}$ Moreover, most blacks live in racially isolated environments that are deprived, if not devastated. A law having the effect of burdening the poor or poorly educated or of reinforcing racial isloation will have the further effect of disproportionately disadvantaging blacks.

\footnotetext{
${ }^{95}$ See note 94 supra \& accompanying text.

${ }^{96}$ See Griggs v. Duke Power Co., 401 U.S. 424, 430 (1971); Gaston County v. United States, 395 U.S. 285 (1969).

${ }^{97}$ See Fiss, $A$ Theory of Fair Employment Laws, 38 U. CHI. L. REv. 235, 239 (1971).
} 
The underlying cause of disproportionate racial impact, the especially disadvantaged social position of black Americans, is one for which American society and government bear a heavy moral responsibility. For well over two hundred years America was a slave society, and, even after the abolition of slavery, American society continued to perpetrate racial discrimination. It simply will not suffice, when assessing moral responsibility, to invoke the metaphysical distinction between "private" discrimination and discrimination propagated by the state. The state is the agent of society, and the state's failure to outlaw private discrimination is simply society's conspiracy with itself to nurture invidious discrimination. The failure of American society to outlaw racial discrimination-at least those instances of discrimination (in schooling, housing, and employment) most destructive to the social position of blacks-was hardly better, as a moral matter, than the discrimination itself. In terms of moral responsibility this failure, which endured for too long, amounted to complicity. Laws having a disproportionate racial impact burden blacks because of their especially disadvantaged position in American society. A failure to require government to take account of that especially disadvantaged social position by selecting and fine-tuning laws to avoid the unnecessary or thoughtless aggravation of the situation would effectively ignore American society's responsibility for that social position. ${ }^{98}$ Furthermore, the failure would compound the responsibility. ${ }^{99}$

${ }^{98}$ See id. $248-49$ \& n. 17.

${ }^{99}$ There are other reasons to incorporate DRI theory into equal protection analysis. Laws having a disproportionate racial impact tend to inflict disadvantages not unlike the disadvantages inflicted by laws employing a racial criterion of selection. In addition, laws having a disproportionate racial impact are connected with the very same social evils-supremacist ideology and racialism-that underlie laws employing a racial criterion. The deliberate use of a racial criterion of selection, we noted earlier, text accompanying note 63 supra, typically has been part of an effort to disadvantage a racial minority and to institutionalize white supremacist notions. Moreover, the deliberate use of a racial criterion encourages racialism, the mental habit of thinking about and dealing with individuals not as individuals but as members of a particular racial group. These considerations underlie the presumptive invalidity of laws employing race as a criterion of selection. To what extent do similar considerations suggest that laws employing no racial criterion but having a disproportionate racial impact should be subject to a burden of justification heavier than mere rationality? By definition, such laws disadvantage blacks to a greater extent than whites. The degree of disadvantage is arguably less when discriminatory purpose is absent, because a discriminatory purpose carries with it a stigma of racial inferiority. But surely the disadvantage-for example, failure to get a job because of a poor performance on a written examination-is serious nonetheless. It might be asked: Isn't the disadvantage the same for a black person who fails an employment test as for a white person who fails the same test? But the question misses the point. The relevant perspective is less that of the disadvantaged individual 
Thus, DRI theory governs disadvantage disproportionately suffered by a racial minority as a consequence of prior societal discrimination against that minority ${ }^{100}$ The theory does not decree, however, that all such disadvantages are unjustified. The DRI standard of review is flexible. Laws employing a racial criterion of selection are inherently more dangerous than laws involving no racial criterion. The former, unlike the latter, directly encourage racialism. ${ }^{101}$ Moreover, laws employing a racial criterion are usually difficult if not impossible to justify on legitimate grounds. By contrast, laws having a disproportionate racial impact are quite easy to explain on legitimate grounds because such laws serve a legitimate function in addition to the function of racial selection. ${ }^{102}$ Accordingly, the standard of review-the burden of justification-contemplated by DRI theory is more rigorous than that required by the rational relationship test but less rigorous than that required by the strict scrutiny test.

The flexible standard of review is rooted in practical considerations as well. It would be unreasonable to require that all tainted disadvantages-disadvantages that are in part the conse-

than the perspective of the entire racial minority. The disproportionate character of the disadvantage, because it constitutes a severe impediment to the racial minority in its difficult struggle to escape the legacy of slavery and oppression and to achieve real social equality, is especially burdensome.

Laws having a disproportionate racial impact but employing no racial criterion of selection, unlike laws employing a racial criterion, are not inherently expressive of white supremacist notions. Nonetheless, laws having a disproportionate impact aggravate the already especially disadvantaged and isolated positions of blacks in American society, and that social position of blacks reinforces supremacist notions of "inherent" white superiority, a superiority thought to explain and to justify the privileged social position of whites. Similarly, although racially "neutral" laws having a disproportionate impact do not directly encourage racialism, they do-in aggravating the social position of black Americans-exacerbate the racial inequality and antipathies that promote the habit of thinking of individuals as "black" or "white." Acceptance of DRI theory, with its requirement that laws having a disproportionate racial impact withstand a burden of justification heavier than mere rationality, would reflect the fact that such laws tend to inflict disadvantages and to reinforce social evils comparable to the disadvantages and evils accompanying laws employing race as a criterion of selection.

${ }^{100}$ Before a law is presumptively unconstitutional under DRI theory, therefore, three factors must be present. First, the plaintiff must be a member of a group that has suffered from a history of discrimination and that is still suffering from that discrimination. Second, there must be government action that disproportionately affects the group. And third, there must be some causal connection between the history of discrimination and the disproportionate character of the impact. In most cases, however, there will be little controversy over the presence of these factors. The crucial issue is more likely to be whether the disproportion is greater than necessary to achieve the governmental objective.

${ }^{101}$ See note 62 supra.

${ }^{102}$ See text accompanying notes 84-85 supra. 
quence of prior societal discrimination-be undone. Some laws having a disproportionate racial impact may be reasonable efforts to achieve a present social good. For example, a hiring practice having a disproportionate racial impact may nonetheless be job-related and hence necessary in order to screen out unqualified job applicants.

In determining whether a disproportionate disadvantage is justified, a court would weigh several factors: (1) the degree of disproportion in the impact; ${ }^{103}(2)$ the private interest disadvantaged; (3) the efficiency of the challenged law in achieving its objective and the availability of alternative means having a less disproportionate impact; and (4) the government objective sought to be advanced. Consider, for example, a challenge to a written examination used to screen applicants for public employment, as in Washington $v$. Davis. A showing of significant disproportionate impact would require the employer to establish that the examination does in fact accurately measure the precise skills demanded by the specific job in question. If the examination could not be validated in this fashion, the employer would have to design a more finely-tuned examination-one that might or might not have a disproportionate impact but that, even if it had the same impact as the challenged examination, would pass muster under DRI theory if it were sufficiently job-

${ }^{103}$ Or the degree of racial imbalance (in the classroom, or in the suburb and nearby urban neighborhoods) caused or reinforced by the challenged action. Courts have responded successfully to the "how disproportionate is disproportionate enough" problem in applying the statutory disproportionate impact test of Title VII's fair employment provisions, 42 U.S.C. $\$ \S 2000 \mathrm{e}-2000 \mathrm{e}-15$ (1970), as amended, 42 U.S.C. $\$ \S$ 2000 e-16 to $2000 \mathrm{e}-17$ (Supp. V 1975), and there is no reason why they could not respond just as successfully in applying a constitutional disproportionate impact test. See Ely, supra note 28 , at $1256-57$ :

[O]ne is surely entitled to ask "disproportionate as compared to what"-the racial distribution in the nation, the state, or the surrounding area, however that might be defined? And assuming that question can be answered, how disproportionate is disproportionate enough?

... The fact that no standards push themselves forward for determining the degree of disproportion which should be required to trigger intervention cannot [count as a refutation of a disproportionate racial impact approach] either. Were the Court to conclude that an affirmative requirement of "balanced" impact would best serve the values underlying the guarantee of equal protection, the chain of reasoning by which that conclusion was established presumably would suggest guidelines which could be given specific content on a case by case basis. Courts have proceeded thus in other legal contexts; there is no reason to think they could not do so here.

Professor Ely subsequently argues against affirmative action theory in the jury selection context, id. 1257-61, not against DRI theory. Ely.did not confuse the two, but he did fail to distinguish them in developing arguments that have force only as applied to affirmative action theory. 
related. In this example, the weights of the private interest disadvantaged, employment, and of the objective sought to be advanced, securing competent employees, are both substantial, and the job-relatedness requirement accommodates both interests. ${ }^{104}$

It is important not to confuse DRI theory with affirmative action theory. The latter is considerably more problematic than the former. Whereas affirmative action theory calls for government to undo the effects of prior discrimination, DRI theory is premised on the notion that government should not exacerbate the effects of prior discrimination any more than is reasonably necessary to achieve the governmental objective. Thus, DRI theory, unlike affirmative action theory, does not call for the allocation of scarce goods and resources to racial minorities with the consequence that these scarce goods and resources are denied to at least some nonminority persons. It requires only that government, in certain contexts, not rely on laws or practices having a disproportionate racial impact. A poor or poorly educated white benefits from the absence of laws disadvantaging poor or poorly educated persons no less than a poor or poorly educated black. Conversely, an affluent, highly educated black person living in an integrated suburb gains nothing from the absence of laws disadvantaging poor or poorly educated persons. ${ }^{105}$ The laws preferred by DRI theory apply to blacks and whites in exactly the same way. The laws favored by affirmative action theory do not.

${ }^{104}$ See text accompanying note 146 infra. An additional point merits mention. In a society too long riven by slavery and even now not wholly exorcised of racism, the possibility always exists that a law disproportionately disadvantaging blacks, while involving no visible discriminatory purpose, will nonetheless have as its principal motive a concealed desire to discriminate against blacks. See, e.g., Baker v. Columbus Mun. Separate School Dist., 462 F.2d 1112 (5th Cir. 1972); cf. Perry, Substantive Due Process Revisited: Reflections on (and Beyond) Recent Cases, 71 Nw. U.L. REv. 417 (1976) (discussing Andrews v. Drew Mun. Separate School Dist., 371 F. Supp. 27 (N.D. Miss, 1973), aff'd, 507 F.2d 611 (5th Cir.), cert. granted, 423 U.S. 820 (1975), cert. dismissed, 96 S. Ct. 1752 (1976)). DRI theory and the judicial function it contemplates speak to just this possibility. In this society, with its sad history of racial oppression, those whose laws or practices disproportionately disadvantage blacks should bear the burden of establishing that such a law bears a substantial relation to its purported objective; that alternative routes to the same objective will not work nearly as well; and that the objective outweighs the disadvantage disproportionately inflicted on blacks. Even this showing does not guarantee that an invisible discriminatory purpose is not present, but it does diminish that possibility.

${ }^{105}$ Indeed, if tomorrow black Americans, as a class, miraculously achieved the exact same level of economic well-being and educational attainment that upper middle class white Americans now enjoy, the existence of laws enacted pursuant to an effort to avoid burdening the poor or poorly educated or reinforcing racial isolation would not give black Americans any advantage over white Americans. 
It has been suggested that a nonmotivational theory of racial discrimination, in requiring government to accommodate the interests of racial minorities, is color conscious and thus weakens the effort of government to inculcate colorblindness in our socio-political life. ${ }^{106}$ This objection, which is perhaps the most telling argument against affirmative action, has a considerably diminished force when directed at DRI theory. As just explained, DRI theory does not call for the allocation of scarce resources to minority members on the basis of race. As we will see below, DRI theory is applicable principally in three contexts: employment, land use planning, and education. The impact of DRI theory on public employment is not to require "quotas," but only to require hiring practices that are validated as job-related. The impact of DRI theory on land use policy is, again, not to require quotas, but only to require the disestablishment of certain land use barriers to the construction of low income housing. Thus, with respect to employment and land use planning DRI theory does not entail color consciousness in either the terms or administration of official policy.

The impact of DRI theory on educational policy is to require that student assignment and other administrative decisions be designed, where practicable, to avoid racially imbalanced schools. In this sense, student assignment decisions would be color conscious, but it is difficult to avoid racial isolation in the classrooms without taking note officially of what is known unofficially anyway: the racial identity of the neighborhoods. Thus, DRI theory does not contribute substantially to color consciousness in any of the three contexts in which it will be most applicable. ${ }^{107}$

${ }^{106}$ See note 62 supra.

${ }^{107}$ DRI theory would be applicable to site selection policies of public housing authorities by requiring housing officials, in their selection of sites, to avoid reinforcing residential racial imbalance. This requirement, like the requirement that school officials act, when practical, to avoid creating racially imbalanced classrooms, does entail color consciousness. But, again, that consciousness-an awareness of the racial identity of neighborhoods-exists anyway. Moreover, federal statutory law already requires that site selection policies be designed to improve residential racial balance. See Housing and Community Development Act of 1974, 42 U.S.C. §§ 1437(a), (f), 5301-5317 (Supp. IV 1974). The federal regulations on site selection for HUD projects also require an awareness of the racial composition of the area. See 24 C.F.R. $\S \S 880.112$ (d), .203(b), 883.209(a) (1976). For a discussion of the effect of federal law in this area, see Hills $v$. Gautreaux, 96 S. Ct. 1538, 1548-50 (1976). 


\section{The Flexibility and Contextually Limited Character} of Disproportionate Racial Impact Theory

In rejecting the disproportionate impact theory of racial discrimination in Washington v. Davis, the Supreme Court failed to comprehend two important features of the theory: the flexibility of its standard of review and its contextually limited character. The Court seemed to assume, mistakenly, that the strictest scrutiny, with its requirement of compelling justification, would be demanded by disproportionate impact theory. ${ }^{108}$ Furthermore, whereas a claim based on discriminatory purpose-the deliberate use by government of race or its functional equivalent as a criterion of selection-can exist in any context and render any government action presumptively unconstitutional, a claim based on disproportionate racial impact, as a practical matter, can exist in only a limited number of contexts and can succeed in even fewer. ${ }^{109}$

\section{A. The Flexibility of DRI Theory}

In rejecting DRI theory, the Washington Court expressed concern that acceptance and application of the theory might result in the invalidation of government-imposed fees, priorities in the distribution of scarce welfare monies, and minimum wage and usury legislation. Such legislation, suggested the Court, "may be more burdensome to the poor and to the average black than to the more affluent white."110 Further reflection could have dispelled the Court's concern. Under DRI theory, the bare fact of disproportionate impact has limited significance. The fact of disproportionate impact does no more than trigger application of the disproportionate impact standard of review. At this point factors other than disproportionate impact become crucial, principally the private interest, in relation to which there is a disproportionate impact, and the public interest, the pursuit of which by means of the challenged law or practice has a disproportionate impact.

${ }^{108}$ See 96 S. Ct. at 2051-52.

${ }^{109}$ It should be clear now why DRI theory does not simply displace the motivational theory of racial discrimination. First, DRI theory is contextually limited. Second, the DRI standard of review is more flexible and less strict than the standard governing laws employing a racial criterion of selection.

$11096 \mathrm{~S}$. C. at 2051-52 \& n.14. 
Consider the suggestion that application of DRI theory might result in the invalidation of government-imposed fees for goods and services. Obviously the government's interest in a quid pro quo is substantial. The public fisc is not inexhaustible. An individual's interest in receiving, for nothing or at reduced cost, goods or services that carry a price tag is not usually recognized as legitimate. Certainly, it is not substantial. ${ }^{111}$ There is an exception with respect to particular commodities, such as a criminal trial transcripts, which are deemed indispensable to the preservation of fundamental values. ${ }^{112}$ Existing constitutional doctrine, however, already deals with such exigencies. ${ }^{113}$ DRI theory would not invalidate government fees for goods and services except in those rare instances in which existing constitutional doctrine already would dictate the same result.

Consider next the suggestion that DRI theory might invalidate legislatively determined priorities in the distribution of scarce welfare monies. In Jefferson $v$. Hackney, ${ }^{114}$ cited by the Court in Washington in rejecting disproportionate impact theory, ${ }^{115}$ recipients of Aid to Families with Dependent Children (AFDC) challenged on equal protection grounds a Texas welfare program under which recipients of Old Age Assistance (OAA) were funded at $100 \%$ of established need, recipients of Aid to the Blind and Disabled (ABD) were funded at 95\%, and AFDC recipients at only $75 \%$. The plaintiffs argued that because racial minorities were disproportionately represented among the AFDC class, funding $\mathrm{OAA}$ and $\mathrm{ABD}$ recipients at a higher percentage of need than AFDC recipients disproportionately disadvantaged racial minorities. The Court in Jefferson rejected plaintiffs' nonmotivational theory of racial discrimination, ${ }^{116}$ but even if the Court had embraced and applied DRI theory the result would have been the same.

Although the AFDC recipients' interest in receiving additional welfare monies is certainly not insignificant, the public's

${ }^{11}$ Cf. Michelman, The Supreme Court, 1968 Term-Foreword: On Protecting the Poor Through the Fourteenth Amendment, 83 HaRv. L. REv. 7, 28 (1969) ("We usually regard it as both the fairest and most efficient arrangement to require each consumer to pay the full market price of what he consumes, limiting his consumption to what his income permits.")

${ }^{112}$ See, e.g., Griffin v. Illinois, 351 U.S. 12 (1956).

${ }^{113}$ See, e.g., Roberts v. LaVallee, 389 U.S. 40, 42 (1967); Douglas v. California, 372 U.S. 353 , 355-58 (1963); Griffin v. Illinois, 351 U.S. 12 (1956).

114406 U.S. 535 (1972).

11596 S. Ct. at 2048.

116406 U.S. at 548-49. 
interest in allocating its scarce welfare resources as it sees fit is quite substantial. The familiar principle that a state may attack only a part of a problem and is not required to attack the whole problem ${ }^{117}$ has particular force when the state is allocating welfare monies. ${ }^{118}$ Moreover, there is nothing inherently suspicious about a state's decision to favor, as a matter of social policy, a "natural" class, such as indigent old people, that includes members of racial minorities. ${ }^{119}$ In Jefferson, the equities were clearly with the state, and the state's interest plainly outweighed the interest of the AFDC recipients. ${ }^{120}$

Consider finally the suggestion that application of DRI theory might invalidate minimum wage and usury laws. ${ }^{121}$ The premise of this suggestion is that such laws do more harm than good for poor people-and thus to blacks who are disproportionately represented among the poor-by diminishing the total number of menial jobs available and by preventing poor people from getting loans. That, however, is a complex economic judgment of precisely the sort that courts, at least since the $1930 \mathrm{~s}$, have been loath to make. ${ }^{122}$ Unless a court is prepared to presume, contrary to the implicit legislative judgment, that minimum wage and usury laws disadvantage the poor, the presumption must be that such legislation benefits the poor. Given that presumption, grounded in traditional and appropriate judicial deference to legislative judgments respecting complex eco-

${ }^{117}$ See, e.g., Williamson v. Lee Optical, Inc., 348 U.S. 483, 489 (1955).

${ }^{118}$ See Dandridge v. Williams, 397 U.S. 471, 487 (1970): "[T] nomic, social, and even philosophical problems presented by public welfare assistance programs are not the business of this Court. . . [ [T] $]$ he Constitution does not empower this Court to second-guess state officials charged with the difficult responsibility of allocating limited public welfare funds among the myriad of potential recipients."

119 See Jefferson v. Hackney, 406 U.S. 535, 548 \& n.17 (1972) (statistics showing that "the number of minority members in all [welfare] categories is substantial").

${ }^{120}$ A contrary conclusion would necessarily entail the proposition that the state could not have a welfare program for old people alone. If the state has discretion to provide welfare for the aged without incurring an obligation to provide welfare for other needy classes, as surely it does, a fortiori it may provide greater welfare benefits for the aged than for a distinct group funded at a diminished level of need-at least it may as a constitutional matter. In Jefferson, the dissent contended that Congress, by statute, had provided that once a state participates in a federally-funded welfare program (e.g., AFDC), it must participate on the same basis that it participates in every other federally-funded welfare program (e.g., OAA and ABD). Id. at 577-82 (Marshall, J., joined by Brennan, J., dissenting).

121 The Washington Court cited, in this regard, Silverman, Equal Protection, Economic Legislation, and Racial Discrimination, 25 VAND. L. REv. 1183 (1972). 96 S. Ct. at 2052 n.I4.

${ }^{122}$ See Perry, Substantive Due Process Revisited: Reflections on (and Beyond) Recent Cases, 71 Nw. U.L. REv. 417 (1976). 
nomic matters, there is no disadvantage to the poor and therefore no occasion for application of DRI theory.

The Supreme Court, in suggesting that application of DRI theory might invalidate government-imposed fees, priorities in the distribution of scarce welfare resources, and minimum wage and usury laws, failed to consider the intrinsic sensitivity of the DRI standard of review to the character of the interests at stake. The flexibility of DRI review precludes the "parade of horribles" that the Court feared would accompany application of DRI theory.

\section{B. Contexts in Which DRI Theory Is Not Applicable}

\section{Jury Selection}

The Washington Court, in rejecting DRI theory, cited cases holding that a criminal defendant must prove an intent or purpose to discriminate to make out a claim of racial discrimination in jury selection. ${ }^{\mathbf{1 2 3}}$ "[T] he fact that a particular jury or series of juries does not statistically reflect the racial composition of the community does not in itself make out an invidious discrimination forbidden by the [Equal Protection] Clause." ${ }^{24}$ The jury selection cases cited by the Court are largely irrelevant to the public employment context of Washington. That DRI theory is inapplicable in a particular context does not establish its inapplicability in every context. The Court's citation of the jury selection cases as authority for rejecting DRI theory in the context of public employment demonstrates the Court's failure to understand the contextually limited character of DRI theory.

There are three stages in the jury selection process at which racial discrimination can occur. The first is the establishment, by statute, of qualifications for jurors. Of course, statutes setting qualifications for jurors must not employ race as a criterion of selection. ${ }^{125}$ Beyond that, statutes establishing qualifications must recognize that the selection of a jury "from a representative cross

12396 S. Ct. at 2047.

${ }^{124} I d$.

${ }^{125}$ See, e.g., Strauder v. West Virginia, 100 U.S. 303 (1879). The Supreme Court has suggested that even voluntary affirmative action in jury selection, an effort by the state to insure proportional representation of racial minorities on juries, is unconstitutional. See Cassell v. Texas, 339 U.S. 282, 286-87 (1950) (plurality opinion by Reed, J.). There is reason to doubt that Cassell "represents [the Court's] last word, or necessarily even its present thinking, on the permissibility of such attempts in the jury context." Ely, supra note 28, at 1259 (footnote omitted) (emphasis in original). 
section of the community is an essential component of the Sixth Amendment right to a jury trial."126 Qualifications that would have a disproportionate racial impact would offend the sixth amendment. Consequently, there is simply no occasion for application of DRI theory to statutes setting qualifications for jurors.

The second stage at which racial discrimination can occur is the compilation of eligibility lists pursuant to the statutory qualifications. Given qualifications that comport with the sixth amendment, there is no reason why compilation of an eligibility list should have a disproportionate racial impact. If, at this administrative stage, a disproportionate number of blacks are excluded, the inescapable inference is that a discriminatory purpose is operating. ${ }^{127}$ Again, there is no occasion for application of DRI theory.

The final stage at which racial discrimination can occur is the selection of general venires from an eligibility list, or the selection of particular panels from general venires. When the selection process is nonrandom, no reason exists-given qualifications that comport with the sixth amendment and eligibility lists free from the taint of discriminatory purpose-for the selection process to have a disproportionate racial impact. If a non-

126 Taylor v. Louisiana, 419 U.S. 522, 528 (1975). The qualifications set within this constitutional framework are fairly standard: "Nearly every State requires that its jurors be citizens of the United States, residents of the locality, of a specified minimum age, and able to understand English. Many of the States require that jurors be of 'good' character' or the like; some, that they be 'intelligent' or 'well informed.' " Carter v. Jury Comm'n, 396 U.S. 320, 333 (1970) (footnotes, containing compilation of statutes, omitted).

${ }^{127}$ See, e.g., Turner v. Fouche, 396 U.S. 346, 361 (1970). It is possible that at this stage of jury selection jury commissioners will compile lists of eligible jurors by including only those qualified individuals known to them personally or through acquaintances, club membership lists, or the like. In that case the commissioners have created a de facto qualification: in order for an otherwise qualified individual to be a juror, a jury commissioner must know him personally or through specific channels. A commissioner proceeding in this fashion has a constitutional duty, under the sixth amendment's "fair cross section" requirement, to acquaint himself with qualified individuals from all segments of the community. See Swain v. Alabama, 380 U.S. 202, 207 n.4 (1965).

Significanty, prior to the emergence of the sixth amendment's "fair cross section" requirement in Taylor v. Louisiana, 419 U.S. 522 (1975), the Supreme Court had held: "Where jury commissioners limit those from whom grand juries are selected to their own personal acquaintance, discrimination can arise from commissioners who know no negroes as well as from commissioners who know but eliminate them. If there has been discrimination, whether accomplished ingeniously or ingenuously, the conviction cannot stand." Smith v. Texas, 311 U.S. 128, 132 (1940). This statement reflects an application of DRI theory to a claim of racial discrimination in jury selection-an application doubtless motivated by the Court's suspicion that discriminatory purpose might be present even though, as an evidentiary matter, invisible and thus not available as a ground of decision. 
random selection process somehow excludes blacks, the inference is inescapable that a discriminatory purpose is the cause. Once again, there is no occasion for application of DRI theory.

The selection of a general venire or a particular grand jury panel may be random, and the selection of a particular petit jury panel, except for peremptory challenges ${ }^{128}$ and challenges for cause, is usually random. Selection that is authentically randomagain, given qualifications that comport with the sixth amendment and eligibility lists free from the taint of discriminatory purpose-cannot have a disproportionate racial impact. ${ }^{129}$ If blacks are somehow excluded in the purportedly "random" process of selecting juries, the inference is inescapable that the process was not random and, moreover, was infected with a discriminatory purpose. ${ }^{130}$ As before, there is no occasion for application of DRI theory.

Thus, DRI theory is inapplicable in the context of jury selection. ${ }^{131}$ The Court's citation of the jury selection cases as authority for rejecting DRI theory in the context of public employment demonstrates the Court's failure to understand that the jury selection context is quite unlike the public employment context and others in which government actions truly lacking a discriminatory purpose can have a disproportionate racial impact nonetheless.

\section{Legislative Districting}

As further authority for rejecting DRI theory, the Wash-

${ }^{128}$ Peremptory challenges present a special problem. See Swain v. Alabama, 380 U.S. 202, 209-28 (1965); United States v. Carter, 528 F.2d 844, 847-50 (8th Cir. 1975), cert. denied, 96 S. Ct. 1745 (1976).

${ }^{129}$ Of course, random selection will not result in the proportional representation of racial minorities on each and every jury panel selected, but over the long run authentic random selection will result in proportional representation.

${ }^{130}$ See, e.g., Avery v. Georgia, 345 U.S. 559 (1953).

${ }_{131}$ The suggestion that racial minorities are entitled to proportional representation on individual jury panels, consistently rejected by the Supreme Court, see, e.g., Akins v. Texas, 325 U.S. 398, 403-04 (1945), proceeds from affirmative action theory. The suggestion is in no way supported by DRI theory. The language of the Supreme Court in Akins, quoted by the Court in Washington, $96 \mathrm{~S}$. Ct. at 2047, holding that a discriminatory purpose must be shown to substantiate a claim of racial discrimination in jury selection, was directed not against DRI theory, but against the affirmative action notion that racial minorities are constitutionally entitled to proportional representation on individual juries. See Akins v. Texas, 325 U.S. at 403 . There is a fundamental difference between a requirement that a law not have a disproportionate racial impact absent adequate justification and a requirement that a law employ a racial criterion of selection in order to achieve proportionality. DRI theory requires only the former; affirmative action theory requires the latter. See note 103 \& text accompanying notes 104-05 supra. 
ington Court cited Wright v. Rockefeller, ${ }^{132}$ which, as the Court described,

upheld a New York congressional apportionment statute against claims that district lines had been racially gerrymandered. The challenged districts were made up predominantly of whites or of minority races, and their boundaries were irregularly drawn. The challengers did not prevail because they failed to prove that the New York legislature "was either motivated by racial considerations or in fact drew the districts on racial lines"; the plaintiffs had not shown that the statute "was the product of a state contrivance to segregate on the basis of race or place of origin." ... The dissenters were in agreement that the issue was whether the "boundaries ... were purposefully drawn on racial lines." 133

The Court's citation of Wright, like its citation of the jury selection cases, was inappropriate; it failed to explore the differences between the legislative districting context and the context in issue, public employment.

Claims that a legislative districting scheme is racially discriminatory usually allege either racial gerrymandering ${ }^{134}$ or the discriminatory operation of a multimember district in which representatives are elected on an "at large" basis. ${ }^{135}$ In either case, the basic complaint is that the districting scheme minimizes the political power of the complaining racial minority. ${ }^{136} \mathrm{But}$, al-

132376 U.S. 52 (1964).

${ }^{133} 96$ S. Ct. at 2047-48 (quoting Wright v. Rockefeller, 376 U.S. 52, 56, 58 (1964)) (citations omitted).

${ }^{134}$ See, e.g., Wright v. Rockefeller, 376 U.S. 52 (1964).

${ }^{135}$ See, e.g., White v. Regester, 412 U.S. 755, 765-70 (1973); Whitcomb v. Chavis, 403 U.S. 124 (1971).

${ }^{136} \mathrm{~A}$ districting scheme may be designed to maximize the political power of a racial minority, and a complainant who is not a member of the racial minority may contend that his group's power has been minimized impermissibly. "Benign" racial gerrymandering can be a two-edged sword even with respect to the minority that was the intended beneficiary. While the affected racial minority gains in the way of political clout in one district, it may lose what political influence it had in others. $C f$. Wright v. Rockefeller, 376 U.S. 52, 57-58 (1964) (voters disagree on desirability of distributing minority groups among districts). Benign racial districting by the New York legislature was recently upheld in the face of a constitutional challenge in United Jewish Organizations of Williamsburgh, Inc. v. Wilson, 510 F.2d 512 (2d Cir.), cert. granted sub nom. United Jewish Organizations of Williamsburgh, Inc. v. Carey, 96 S. Ct. 354 (1975). See Note, Proportional Representation by Race: The Constitutionality of Benign Racial Redistricting, 74 Mrch. L. Rev. 820 (1976); $c f$. Bittker, The Case of the Checker-Board Ordinance: An Experiment in Race Relations, 71 YALE L.J. 1387, 1414-15 (1962) (racial minorities are not entitled to proportional representation). 
though a multimember scheme, ${ }^{137}$ for example, disadvantages blacks to the extent that it minimizes their voting power, this disadvantage is not a consequence of the history of discrimination to which blacks have been subject. ${ }^{138} \mathrm{~A}$ multimember scheme does not disadvantage blacks because they, as a group, are poor, poorly educated, or racially isolated. Rather, it disadvantages them only because they are a minority group. The status of black people as a minority group is not the legacy of slavery or discrimination. Blacks are one minority group among many: some groups are racially defined, others are defined by a common interest or concern. In being disadvantaged as a political interest group, blacks are affected in the same way as any other interest group tending to congregate in a common neighborhood (such as poor people, apartment dwellers, and shopkeepers). ${ }^{139}$ All such groups would stand a better chance of electing someone sympathetic to their special interests if their electoral jurisdiction were a smaller, single-member unit. The principle is the same if the issue is not multi- versus single-member districts, but district line-drawing, "gerrymandering."

Of course, blacks are much more likely than nonracial minority groups to suffer from a multimember scheme, because blacks have been and remain the victims of virulent discrimination. If a court finds that a multimember scheme is used by local political actors or by the voting citizenry as a vehicle of racial discrimination, it may disestablish the vehicle of discrimination, the multimember district. ${ }^{140}$ The rationale for striking down such a multimember scheme is that it, as a vehicle of intentional

${ }^{137}$ Most claims of racially discriminatory districting are directed against multimember districts. See, e.g., cases cited note 135 supra; Dove v. Moore, 45 U.S.L.W. 2064 (8th Cir. July 27, 1976); McGill v. Gadsden County Comm'n, 535 F.2d 277 (5th Cir. 1976); Nevett v. Sides, 533 F.2d 1361 (5th Cir. 1976); Kendrick v. Walder, 527 F.2d 44 (7th Cir. 1975); Blacks United for Lasting Leadership, Inc. v. Shreveport, 45 U.S.L.W. 2052 (W.D. La. July 16, 1976).

${ }^{138}$ See note 100 supra.

${ }^{139}$ That blacks, like other minority political interest groups, do not invariably enjoy success at the polls, does not in itself present a constitutional problem. See Whitcomb v. Chavis, 403 U.S. 124, 153 (197I). Moreover, the Supreme Court has consistently rejected the affirmative action notion, see note 131 supra, that racial minorities-or minorities of any kind-are constitutionally entitled to proportional representation by members of their own race and, therefore, to districting schemes that guarantee such representation. See Beer v. United States, 96 S. Ct. 1357, 1361 n.8 (1976); Whitcomb v. Chavis, 403 U.S. 124, 149 (1971); Kilgarlin v. Martin, 252 F. Supp. 404, 432-33 (S.D. Tex. 1966), rev'd per curiam on other grounds sub nom. Kilgarlin v. Hill, 386 U.S. 120 (1967). See also Panior v. Iberville Parish School Bd., 536 F.2d 101, 104 (5th Cir. 1976); cases cited in Note, supra note 136, at 824 n.26.

${ }^{140}$ See, e.g., White v. Regester, 412 U.S. 755, 765-70 (1973). 
racial discrimination, is infected with discriminatory purpose. ${ }^{141}$ Thus, DRI theory is not applicable to legislative districting schemes. When operating without the taint of discriminatory purpose, a districting scheme disadvantages blacks, if at all, in essentially the same way it disadvantages other minority interest groups in the political process. When operating as a vehicle of racial discrimination-and in that sense disadvantaging blacks in a way other groups are not disadvantaged, deliberately, on the basis of race-a districting scheme is infected with discriminatory purpose and can, on that motivational ground, be struck down. ${ }^{142}$

\section{Contexts in Which DRI Theory Is Applicable}

\section{Public Employment}

Hiring and promotion practices similar to the written examination at issue in Washington or the requirement of a high school diploma ${ }^{143}$ place a premium on educational achievement and thus impose a burden on those whose educational attain-

${ }^{141}$ The Supreme Court and lower federal courts, most notably the Court of Appeals for the Fifth Circuit, have endeavored to isolate those factors that, if proved, will sustain a conclusion that a multimember district has been used as a vehicle of racial discrimination. See, e.g., id. at 766-67; Zimmer v. McKeithen, 485 F.2d 1297, 1305 (5th Cir. 1973), aff'd per curiam sub nom. East Carroll Parish School Bd. v. Marshall, 96 S. Ct. 1083 (1976). Although White v. Regester, 412 U.S. 755 (1973), is the only case in which the Supreme Court has ruled against multimember schemes, the Court has advised the lower federal courts that, in devising reapportionment plans, it should favor singlemember districts as a matter of policy. Chapman v. Meier, 420 U.S. 1 (1975). This recommendation is somewhat ironic because multimember districts were once viewed as progressive reform measures serving the interests of good government rather than parochialism. See Kendrick v. Walder, 527 F.2d 44, 51 (7th Cir. 1975) (Pell, J., dissenting) (citing relevant historical materials).

${ }_{142}$ There are, of course, contexts besides jury selection and legislative districting in which DRI theory is inapplicable. Consider, for example, criminal law enforcement. Police and prosecutors are expected to attack crime where they find it and to fail to attack it only for legitimate policy reasons. If in a certain community a disproportionate number of blacks violate a particular law, or violate it more visibly than others, the fact that enforcement of the law results in the prosecution of a disproportionate number of blacks presents no constitutional problem. Criminal law enforcement, even selective prosecution, offends equal protection only when an illegitimate criterion of selection-for example, race, religion, or political beliefs-is employed. Note, for example, that concentrating undercover agents in a black neighborhood where most heroin transactions are known to occur does not involve the use of race as a criterion of selection. The criterion is the volume of illicit transactions occurring. See, e.g., Oyler v. Boles, 368 U.S. 448 (1962); cf. Snowden v. Hughes, 321 U.S. 1 (1944) (absent discriminatory motive, electoral body did not deny plaintiff equal protection by refusing to certify him as nominee for state office). See generally Y. Kamisar, W. LAFave \& J. IsRael, Modern Criminal Procedure 840-58 (4th ed. 1974).

${ }^{143}$ See Griggs v. Duke Power Co., 401 U.S. 424 (1971). 
ment, in the form of either intellectual or vocational skills, is comparatively weak. Blacks are disproportionately represented among those whose educational achievement is weak, and this condition is part of the legacy of slavery and racial oppression. Not only have blacks been discriminated against in education, but the impact of slavery and discrimination on the family and social structures of many blacks has seriously impaired the motivation and ability of many black children to succeed in the classroom. Because there is a disproportionate impact, a history of discrimination, and a causal connection between them, the DRI standard of review should apply. ${ }^{144}$

An individual's interest in having a job, and as good a job as possible, is certainly very great. Employment is essential to material well-being and basic emotional satisfaction; as such, the right to work may be even more precious than the right to vote. ${ }^{145}$ An employer's interest in hiring only those qualified to do the job, or those most qualified, is also great, and this becomes a societal interest when the employer is a government agency. ${ }^{146}$ The requirement that a hiring practice bear a demonstrable relation to job performance accommodates both interests. Specifically, the requirement assures that the impact will not be more disproportionate than necessary to secure the government's interest in qualified employees. The decision not to apply DRI theory to hiring practices like that challenged in Washington implies-given the lenient demands of minimal scrutiny ${ }^{\mathbf{1 4 7}}$ - that it is legitimate, as a constitutional matter, for government to

${ }^{144}$ See note 100 supra. Employment is also important to the minority group to which the individual belongs because that group can fully overcome the history of discrimination only as its members acheive economic well-being.

${ }^{145}$ See Fiss, supra note 97, at 294.

${ }^{146}$ DRI theory also would apply to procedures whereby government certifies persons to practice a given profession. Title VII does not govern such certification procedures. Courts have disagreed on the propriety of applying DRI theory in this context. Compare Tyler v. Vickery, 517 F.2d 1089 (5th Cir. 1975), cert. denied. 44 U.S.L.W. 3719 (U.S. June 15, 1976) (rejecting a disproportionate impact challenge to the Georgia bar examination, which all 40 black applicants failed in July 1972; applying rational relationship test), and Richardson v. McFadden, 45 U.S.L.W. 2130 (4th Cir. Aug. 14, 1976) (rejecting disproportionate impact challenge to the South Carolina bar examnation; "fair and substantial" job-relatedness required), with Baker v. Columbus Mun. Separate School Dist., 462 F.2d 1112 (5th Cir. 1972) (sustaining a challenge to use of the National Teachers Examination as a condition of employment; strict scrutiny test applied), Walston v. County School Bd., 492 F.2d 919 (4th Cir. 1973) (sustaining a disproportionate impact challenge to use of the National Teachers Examination; applying jobrelatedness requirement), and United States v. North Carolina, 400 F. Supp. 343 (E.D.N.C. 1975) (sustaining a disproportionate impact challenge to use of National Teachers Examination; applying job-relatedness test).

${ }^{147}$ See Washington v. Davis, 96 S. Ct. 2040, 2051-52 (1976). 
employ a device that excludes a disproportionate number of blacks even though it fails to bear a demonstrable relation to job performance and thus fails to advance effectively government's interest in employing qualified workers. ${ }^{148}$ It is difficult to discern any justification for this proposition. ${ }^{149}$

${ }^{148}$ Title VII of the Civil Rights Act of 1964, 42 U.S.C. $\$ \$ 2000 \mathrm{e}-2000 \mathrm{e}-15$ (1970), as amended, 42 U.S.C. $\$ \S 2000 \mathrm{e}-16$ to $2000 \mathrm{e}-17$ (Supp. V 1975), did not apply to public employment until 1972. The plaintiff in Washington did not rely on Title VII, because the suit was commenced before passage of the public employment amendments, and the procedural prerequisites for a Title VII action were never satisfied. The original provisions of Title VII were enacted pursuant to Congress' commerce power. Fitzpatrick v. Bitzer, 96 S. Ct. 2666, 2670 (1976). The public employment amendments were enacted pursuant to Congress' power under $\S 5$ of the fourteenth amendment to enforce the provisions of $\S 1$ of that amendment. Id. at $2670 \&$ n.9.

Unless the normative content of the equal protection clause is one thing when Congress is enforcing the clause and something else when the Court is enforcing it, it is impossible to understand how fourteenth amendment enforcement legislation (Title VII public employment provisions) can rest on a nonmotivational theory of racial discrimination when the very clause being enforced, as the Court in Washington construed it, excludes such a theory. Oregon v. Mitchell, 400 U.S. 112, 205-09 (1970) (Harlan, J., concurring in part and dissenting in part); id. at 248 (Brennan, White \& Marshall, JJ., concurring in part and dissenting in part); id. at 293-96 (Stewart, J., joined by Burger, C.J. \& Blackmun, J., concurring in part and dissenting in part), establishes that the normative content of a constitutional provision is the same for both Congress and the Court. Given Oregon v. Mitchell, Washington's rejection of DRI theory is logically inconsistent with the proposition that Congress, by way of enforcing the equal protection clause, may forbid the states to use any hiring practice having a disproportionate racial impact that does not bear a demonstrable relation to job performance. Only one of the two theories-Washington or the proposition just cited-can prevail, for the two are mutually exclusive. Because the latter is firmly established, the Court, unless it meant to overrule sub silentio Oregon $v$. Mitchell, was simply wrong in Washington in suggesting that the disproportionate impact theory of racial discrimination is somehow alien to the concept of equal protection. The concept of equal protection, properly understood-the way Congress understood it in extending Title VII to employment by the statesaddresses both motivational and nonmotivational modes of racial discrimination.

${ }^{149}$ See Chance v. Board of Examiners, 458 F.2d 1167, 1175-76 (2d Cir. 1972) (concerning public employment): "That harsh racial impact, even if unintended, amounts to an invidious de facto classification that cannot be ignored or answered with a shrug. At the very least, the Constitution requires that state action spawning such a classification "be justified by legitimate state considerations.' " It is especially difficult to justify the proposition in the text given the fact that a hiring practice having a disproportionate impact impedes blacks, who suffer unemployment and menial employment more extensively than other groups, in their struggle to escape the legacy of discrimination. See Blacks-On a New Plateau, Newsweex, Oct. 4, 1976, at 73.

In May 1975, total black joblessness was 14.2 per cent; by August $/ 1976 /$, it had come down only to 13.6 per cent. During the same period, over-all white unemployment fell far faster, from 8.3 per cent to 7.1 per cent.

What's more, the statistics understate the actual extent of the damage, many labor-market analysts contend. In many black households, for instance, men have worked at two jobs just to make ends meet. "When the recession hit, a lot of those second jobs were lost but the man was still not counted as unemployed," says Aaron Turpeau, director of a U.S. Labor Department office in Atlanta. When other anomalies are added to the official jobless estimates, the rate mushrooms. According to its "hidden unemployment index," which takes 


\section{Administration of Public Schools ${ }^{150}$}

Racial imbalance in the classroom reflects the residential racial isolation that pervades our society. This racial isolation is perhaps the most significant consequence of slavery and racial discrimination. ${ }^{151}$ Ghettoization-residential apartheid-is probably the surest sign of a society in which the color of a man's skin has not ceased to matter. The presumptive invalidity of race as a criterion of selection, as noted above, ${ }^{152}$ is premised on the extent to which racial criteria directly disadvantage blacks, institutionalize supremacist ideology, and encourage racialism. Residential racial isolation disadvantages blacks by reinforcing economic deprivation and by inflicting severe socio-psychological dysfunction. Furthermore, by keeping the races separated and imposing inequalities of material wealth and social skills on the minority race, residential racial isolation facilitates the cultural transmission of supremacist ideology and racialism. Racial isolation, then, whether or not a direct consequence of intentional discrimination, is a prolific source of disadvantage to blacks.

Although it is possible to do something about intentional discrimination, it is virtually impossible to do anything about residential racial isolation that is not the direct result of intentional discrimination-impossible, at any rate, to do very much in the short run, and impossible even in the long run without both a societal consensus that something ought to be done and concerted social engineering on several fronts. Even though it is virtually impossible substantially to reduce residential racial isolation in the foreseeable future, it is possible to moderate its adverse impact.

Consider the administration of public schools. Because of residential racial isolation, decisions as to pupil assignment,

account of discouraged and part-time workers who want full-time jobs, the $\mathrm{Na}$ tional Urban League calculates that the over-all rate for blacks in the second quarter $/ 1976 /$ was actually 25.4 per cent. For black teenagers, the rate hit a Id. 74-79. staggering 64 per cent vs. the official count of 40 per cent.

${ }^{150}$ See generally Fiss, Racial Imbalance in the Public Schools: The Constitutional Concepts, 78 Harv. L. Rev. 564 (1965); Goodman, De Facto School Segregation: A Constitutional and Empirical Analysis, 60 CALIF. L. Rev. 275 (1972).

${ }^{151}$ Past discrimination has contributed to present residential racial isolation in at least two important ways. First, discrimination is a major cause of the especially disadvantaged economic status of blacks that forces them into the most deprived neighborhoods. Second, pervasive discrimination in housing underlies segregated neighborhoods.

${ }^{152}$ See text accompanying note 57 supra. 
school site selection, and districting must have the effect of either increasing or decreasing racial imbalance in the classroom. In a quantitative sense, racial imbalance in the classroom does not have a disproportionate racial impact. If there were two schools, one $100 \%$ black and the other $100 \%$ white, there would be perfect imbalance. To the extent that every black and every white student would be racially isolated, however, the quantitative impact of the imbalance would not be disproportionate. But in a qualitative sense, racial imbalance does have a disproportionate impact: it disadvantages the isolated blacks much more grievously than the isolated whites. Research into the effects of racially imbalanced schooling on the educational achievement of minority children is inconclusive. ${ }^{153}$ On one important point, however, a consensus exists: Racial isolation in the schools, like racial isolation in the neighborhoods, facilitates the cultural transmission of stereotyped, supremacist, racialist habits of mind, and these habits nurture yet another generation of racial discrimination, division, and hostility. ${ }^{154}$ Blacks are indisputably the principal victims of this discrimination and hostility. ${ }^{155}$

Just as something can be done, and is done, under the fourteenth amendment, about racial criteria of selection and attendant evils, something can be done about racial isolation in the classroom. Racially imbalanced schools are sometimes inevitable, but not always, and not everywhere. School administrators can be charged with the duty of avoiding, to the extent practical, racially imbalanced schools. School officials should be obligated to consider the potential racial effects of alternative courses of action and inaction, ${ }^{156}$ and, where practical, to choose a course

${ }^{153}$ See Goodman, supra note 150, at 400-35. In August 1976, however, the United States Civil Rights Commission issued a report suggesting "that peaceful desegregation raises educational quality and minority achievement." See Rights Panel is Critical of Ford on Schools, N.Y. Times, Aug. 29, 1976, \& 4, at 4, col. 1. Certainly, social scientific research is a problematic basis for constitutional decisionmaking. See Linde, Judges, Critics, and the Realist Tradition, 82 YALE L.J. 227, 238-44 (1972).

${ }^{154}$ See, e.g., Hart v. Community School Bd., 383 F. Supp. 699, 729-32 (E.D.N.Y. 1974), aff'd, 512 F.2d 37 (2d Cir. 1975); Hobson v. Hansen, 269 F. Supp. 401, 419, 504-05 (D.D.C. 1967), aff'd sub nom. Smuck v. Hobson, 408 F.2d 175 (D.C. Cir. 1969); U.S. Commission on Civil Rights, Racial Isolation in the Public Schools 109-10 (1967); Emerson, Frank, Frey, Griswold, Hale, Havighurst \& Levi, Segregation and the Equal Protection Clause, 34 Mins. L. Rev. 289, $319-20$ (1950); Goodman, supra note 150, at 366 .

${ }^{155}$ This is not to say that whites are unaffected by the tensions, inefficiencies, and inhumanities resulting from racial discrimination.

${ }^{156}$ See, e.g., Hart v. Community School Bd. of Educ., 512 F.2d 37, 50 (2d Cir. 1975); Morgan v. Kerrigan, 509 F.2d 580, 585 (1st Cir. 1974), cert. denied, 421 U.S. 963 
that will minimize racial imbalance. Application to school administration of the disproportionate impact theory of racial discrimination would charge school officials with this obligation. More specifically, application of DRI theory would subject school officials to the requirement that action conducive to racial balance be preferred if practical under the circumstances. ${ }^{157}$ This requirement, obviously, would have to be applied with sensitivity to local detail (and to sham assertions of impracticality). The necessity for sensitive, case by case adjudication is not new and hardly counts as a reason to reject DRI theory. ${ }^{158}$

It has been suggested that judicial reluctance to apply DRI theory to school administration ${ }^{159}$ stems from the fear that application of the theory would necessitate unrealistic and unpopular remedial action such as massive busing. ${ }^{160}$ Again, however, it is important to keep DRI theory and affirmative action notions distinct. DRI theory does not imply a substantive constitutional right to a particular degree of racial mixture in every public school. The Supreme Court has correctly rejected the notion that any such right exists. ${ }^{161}$ Rather, DRI theory contemplates

(1975). But cf. Pasadena City Bd. of Educ. v. Spangler, 96 S. Ct. 2697, 2704-05 (1976) (the district court exceeded its authority in requiring annual readjustment of attendance zones once a neutral attendance plan had been implemented).

${ }^{157}$ See Fiss, supra note 150 , at 608 :

For example, assume that the racial imbalance in a small urban community can be corrected merely by replacing the attendance lines that run north-south with others that run east-west, or by instituting an open transfer plan, or by locating a new school on the fringe of the ghetto. In such a case a court ... [may] conclude that the board's refusal to adopt remedial measures is unjustified.

For a discussion of a variety of mechanisms sometimes available for improving racial balance, see $i d$. 571-74 (open transfer plans; strategic site selection; rezoning without sacrificing geographical compactness; enlargement of attendance zones; busing).

${ }^{158}$ See id. 608 (footnote omitted):

The possibility that a justification may exist prevents courts from making blanket pronouncements that the creation and maintenance of imbalanced schools always violates the equal-educational-opportunity principle.

Since constitutional adjudication demands uniformity, it may appear disturbing that the creation and maintenance of imbalanced schools will violate the equal-educational-opportunity principle only in some communities and in some circumstances. Yet, uniformity is required only in the principle applied, not in the outcome of this application. It is fallacious to assume that either all instances of racial imbalance must be unconstitutional or none are, and this fallacy is nourished by continued use of the term de facto segregation. This term incorrectly suggests that the problem is one involving a monolithic institution, the Northern counterpart of the Jim Crow laws condemned in Brown.

${ }^{159}$ Most courts have not been so reluctant. See note 88 supra.

${ }^{160}$ Fiss, School Desegregation: The Uncertain Path of the Law, 4 Philosophy \& Pub. Afrairs 3, 16-17 (1974).

${ }^{161}$ Pasadena City Bd. of Educ. v. Spangler, 96 S. Ct. 2697, 2703 (1976); Swann v.

Charlotte-Mecklenburg Bd. of Educ., 402 U.S. 1, 24 (1971). 
that school board decisions disserving racial balance be justified by a showing that alternative courses, less hostile to racial balance, are impractical. ${ }^{162}$ DRI theory requires only that school officials act in ways that improve rather than impair racial balance, where it is not unreasonable to do so. ${ }^{163}$ Although it is

${ }_{162}$ DRI theory certainly does not prevent the Supreme Court from laying down equitable ground rules for "practicality," such as the rule that under normal circumstances court-ordered remedial action shall respect school district lines. In effect, the Supreme Court laid down this particular ground rule in Milliken v. Bradley, 418 U.S. 717 (1974) (reversing the district court's grant of multidistrict relief where no showing was made either that there had been purposeful racial segregation in the school districts outside Detroit or that district lines had been drawn with a discriminatory purpose). See Hills v. Gautreaux, 96 S. Ct. 1538 (1976): "[T] limitations on the exercise of the equity power of federal courts and not on a balancing of particular considerations presented by school desegregation cases." Id. at 1544 (emphasis supplied). Understood as relying on equitable doctrine, Milliken is consistent with the requirement of DRI theory that actions by school administrators have as favorable an impact on racial imbalance as is practical given the circumstances. Milliken and Gautreaux seem to leave open the possibility that state courts can fashion equitable decrees in desegregation suits broader than the decrees that federal courts can fashion.

In Washington v. Davis, Justice White rejected DRI theory. White dissented in Milliken, contending that multidistrict relief was in order. In Milliken, however, multidistrict relief was in order, if at all, only on the theory that the underlying right was a right to a racially balanced education where practical. This right logically derives from the nonmotivational, disproportionate impact theory of racial discrimination. If in Milliken the basic right was to have school officials not use race as a criterion of selection, multidistrict relief would have been inappropriate because the Milliken plaintiffs would not have been attending schools outside the Detroit district even if race had never been used as a criterion of selection inside the Detroit district. No evidence in Milliken indicated purposeful racial discrimination in the districts outside Detroit or in the drawing of any district lines. Thus, Justice White's position in Milliken logically entails the nonmotivational theory of racial discrimination that he rejected in Washington.

A further point merits mention here. If the presumed advantages of neighborhood schools, see Fiss, supra note 150, at 566-67; Kaplan, Segregation Litigation and the Schools -Part II: The General Northern Problem, 58 Nw. U.L. REv. 157, 178 (1963) (chiefly avoidance of transportation and associational interests), are weighted so heavily that the interest in neighborhood schools is, in effect, deemed paramount, then there is no point in applying DRI theory, because the interest in maintaining neighborhood schools, in nearly every case of consequence, would justify racial imbalance. Only means short of disestablishing the neighborhood school would be held practical. Thus, a judgment implicit in application of DRI theory to school administration is that the interest in racial balance is weightier than the interest in neighborhood schools.

${ }^{163}$ The recent Atlanta school case, Calhoun v. Cook, 522 F.2d 717 (5th Cir. 1975), demonstrates that sensitive application of DRI theory to school administration need not yield unrealistic results. More than $85 \%$ of Atlanta's 80,000 public school students are black; 92 of 148 public schools are over $90 \%$ black, and black citizens "occupy the majority of posts on the school board, . . . two-thirds of the posts in the school administration and staff and . . . over sixty percent of the faculty." Id. at 719. In rejecting a plea that the defendant school board be required to improve racial balance through "the transportation, zoning and pairing of white students into predominantly black schools," $i d$. at 718, the court of appeals reasoned that "[i]n Atlanta, where white students now comprise a small minority and black citizens can control school policy, administration and staffing," the degree of racial balance in the Atlanta schools is constitutionally adequate, id. at 719 . It might be argued that the court in Calhoun implicitly. 
rather quixotic to expect racially balanced classrooms to cure racial intolerance singlehandedly, at least they do not nurture it; in addition, they can help foster the mutual understanding that precedes tolerance. ${ }^{164}$

The Supreme Court has insisted on maintaining the distinction between de jure and de facto school segregation. The Court has said that "the differentiating factor" between the two is "purpose or intent to segregate." 165 The Court, however, has never

rejected the disproportionate impact test that governs school desegregation cases in the Fifth Circuit. See, e.g., United States v. Texas Educ. Agency, 532 F.2d 380 (5th Cir. 1976) (impact test formulated in terms of the "intent" fiction discussed in notes 165-71 infra \& accompanying text); Cisneros v. Corpus Christi Independent School Dist., 467 F.2d 142, 149 (5th Cir. 1972) ("Discriminatory motive and purpose, while they may reinforce a finding of effective segregation, are not necessary ingredients of constitutional violations in the field of public education."). This argument ignores the fact that Cisneros, Calhoun, and Texas Education Agency were all decided by unanimous panels. Judge John Minor Wisdom was a member of each panel and the author of the court's opinions in Cisneros and Texas Education Agency. It is unlikely that Judge Wisdom would have failed to comment had the Calhoun panel rejected the test he had formulated in Cisneros and preserved in Texas Education Agency.

${ }^{164}$ See note 154 supra. Of course, a community's reaction to a court's desegregation order, as in Boston, can impair, in the short run, the capacity of racially balanced schools to foster understanding and tolerance. $C f$. Rights Panel is Critical of Ford on Schools, N.Y. Times, Aug. 29, 1976, \& 4, at 4, col. l:

The United States Civil Rights Commission has issued a lengthy report on school desegregation that is generally positive on progress but strongly critical of the Ford Administration. The burden of the Commission's findings was that desegregation works peacefully where communities and community leaders want it to; Mr. Ford's legislative proposals to limit the Federal judiciary's busing authority, the commission said, encourages community resistance.

Not insignificantly, DRI theory relieves a school desegregation plaintiff of the burden of establishing that the challenged action was racially motivated. Establishing discriminatory purpose in school desegregation suits can be very difficult and time consuming. DRI theory makes it less likely that a plan motivated by a concealed discriminatory purpose would be upheld.

With respect to the ever-present possibility of covert racial discrimination in school administration, the following is instructive:

The old Jim Crow notion that separate schools for the races were all right as long as they were equal has, of course, been unconstitutional since the U.S. Supreme Court handed down its landmark 1954 decision on Brown v. Board of Education of Topeka (Kans.). Nonetheless, the state of Missouri never got around to deleting a clause from its own constitution calling for "separate schools . . . for white and colored children." Last week the state's voters were finally given a chance to do so. With $90 \%$ of the tally in, the proposition to kill the clause was passed, but by the surprisingly close margin of 527,000 to 390,000 .

The number of voters who wanted to keep the provision in the Missouri constitution was a sad reminder of the latent oppcsition, never too far below the surface, to integrated schools in the U.S. -22 years after the Supreme Court spoke so emphatically on the issue.

Missouri Compromised, TIME, Aug. 16, 1976, at 8.

${ }^{165}$ Keyes v. School Dist. No. 1, 413 U.S. 189, 208 (1973) (emphasis in original). See also 20 U.S.C. $\& 1705$ (Supp. V 1975) (plan for assignment of students on a neighborhood basis does not violate the equal protection clause unless instituted for the purpose of segregation). 
explicitly decided "whether intentional action leading foreseeably to [racial imbalance], but taken without racial motivation, might not also constitute de jure discrimination."166 Several federal courts of appeals, laboring under the Supreme Court's de jure-de facto distinction but persuaded that a disproportionate impact test should govern school desegregation suits, have resorted to a fiction that enables the lower courts to cast their opinions in terms of "intent" and "de jure" segregation even though they focus not on discriminatory purpose but on effects, in terms of racial balance. The courts' theory is that school boards "intend" the natural, foreseeable consequences of their actions. Under this theory, if a school board's action has the effect-which will always be "natural" and "foreseeable" because it is no secret which neighborhoods are predominantly black and which are not-of creating or maintaining racially imbalanced schools, then the school board is said to "intend" the effect and thus to create "de jure" segregation. ${ }^{167}$

The theory is a fiction. It rests on a bastardization of the concept of intent. The "discriminatory purpose" or "intent" that the Supreme Court has invariably required as an element of unconstitutional racial discrimination is the deliberate use of race as a criterion of selection. ${ }^{168}$ This is intent as motivation. The intent on which the lower courts rely does not denote the deliberate use of a racial criterion but consists of foreknowledge of result. This is intent as knowledge; whether or not the result was

${ }^{166}$ Hart v. Community School Bd. of Educ., 512 F.2d 37, 49 (2d Cir. 1975) (discussing Keyes).

${ }_{167}$ This fiction, endorsed by Professor Fiss in 1965 , Fiss, supra note 150 , at $584-85$, is widely used. See, e.g., United States v. Texas Educ. Agency, 532 F.2d 380, 388 (5th Cir. 1976) (" $[\mathrm{A}]$ person intends the natural and foreseeable consequences of his actions.”); Hart v. Community School Bd. of Educ., 512 F.2d 37, 50, 51 (2d Cir. 1975) ("[A] finding of de jure segregation may be based on actions taken, coupled with omissions made, by governmental authorities which have the natural and foreseeable consequence of causing education segregation."). Occasionally, the fiction is phrased in terms of a presumption of segregative design, which a school board can rebut only by proving that its challenged action, creating racially imbalanced schools, was not racially motivated. United States v. School Dist., 521 F.2d 530, 535-36 (8th Cir.), cert. denied, 96 S. Ct. 361 (1975) ("[A] presumption of segregative intent arises once it is established that school authorities have engaged in acts or omissions, the natural, probable and foreseeable consequence of which is to bring about or maintain segregation."); Oliver v. State Bd. of Educ., 508 F.2d 178, 182 (6th Cir. 1974). Given the extraordinary difficulty of establishing the absence of racial motivation, the presumption of segregative design is, for practical purposes, the equivalent of a conclusive presumption.

${ }^{168}$ See Swann v. Charlotte-Mecklenburg Bd. of Educ., 402 U.S. 1, 31-32 (1971). Indeed, that is precisely what Washington $v$. Davis is all about. The Washington Court cites the de jure-de facto distinction in school desegregation cases in support of its rejection of nonmotivational theory of racial discrimination. $96 \mathrm{~S}$. C.t. at 2048 . 
desired is simply not relevant. ${ }^{169}$ The intent fiction effectively collapses the distinction between de jure and de facto segregation. Under the fiction, the use of the neighborhood criterion of selection, when it naturally and foreseeably leads to racially imbalanced neighborhood schools, constitutes de jure segregation even though such schools have always been regarded as "segregated" only in a de facto or adventitious sense. ${ }^{170}$ Use of the intent fiction is simply a mask for application of the disproportionate impact theory of racial discrimination to school desegregation cases. It is difficult to perceive any principled basis on which the Supreme Court can accept the intent fiction in the context of school desegregation while rejecting DRI theory, which the fiction masks, in every other context. ${ }^{171}$

\section{Land Use Policy}

Because a disproportionate number of persons with low income are black, land use decisions that prevent or seriously impede the construction of low income housing communities disproportionately disadvantage black Americans in their pursuit of decent housing. Perhaps more importantly, such decisions have the substantial effect of reinforcing residential racial isolation by fencing the poor, who are disproportionately black, out of predominantly white, relatively affluent communities and into racially isolated neighborhoods. ${ }^{172}$ Moreover, because businesses and jobs increasingly are fleeing the cities for the urban fringe or suburban areas, making it even more difficult for inner city blacks to get work, exclusionary land use decisions aggravate the economic deprivation of blacks by fueling black unemployment. ${ }^{173}$ Economic deprivation and racial isolation are mutually

${ }^{169}$ See, e.g., Hart v. Community School Bd. of Educ., 512 F.2d 37, 51 (2d Cir. 1975) ("[A] lack of racial motivation [is] irrelevant in the face ... of a foreseeable effect.").

${ }^{170}$ See P. Brest, supra note 55 , at 530 n.81.

171 Justice Powell has argued forthrightly against the de jure-de facto distinction. Keyes v. School Dist. No. 1, 413 U.S. 189, 219 (1973) (Powell, J., concurring). If Justice Powell supports application of a disproportionate impact test in school desegregation cases, then he should have explained, in Washington, why he rejected the disproportionate impact test in the context of public employment.

${ }^{172}$ See, e.g., Metropolitan Hous. Dev. Corp. v. Village of Arlington Heights, 517 F.2d 409 (7th Cir.), cert. granted, 96 S. Ct. 560 (1975), discussed in notes 181-92 infra \& accompanying text. Land use practices exacerbating racial isolation include requirements of minimum lot size, exclusion of multifamily dwellings, and limitations on the number of bedrooms per housing unit. See Comment, Applying the Title VII Prima Facie Case to Title VIII Litigation, 11 HARv. C.R.-C.L.L. Rev. 128, 132-33 \& n.30 (1976).

${ }^{173}$ See note 140 supra. 
reinforcing: poverty makes it difficult to escape racially isolated neighborhoods, and racial isolation makes it difficult to escape poverty. If ever there were a vicious circle, economic deprivation and racial isolation describe it. ${ }^{174}$ Exclusionary land use decisions therefore have a disproportionate racial impact because they disproportionately disadvantage blacks in their pursuit of decent housing and employment. In addition, and more fundamentally, racial isolation is an incubator of racial discrimination. ${ }^{175}$

A decision not to apply DRI theory to exclusionary land use decisions would overlook the nature and gravity of the underlying social problems. Racial polarization is increasing, as the Kerner Commission warned eight years ago. ${ }^{176}$ Whites are fleeing the cities in growing numbers, and blacks remain behind in neglected, disintegrating, even devastated neighborhoods. ${ }^{177} \mathrm{Be}-$

${ }^{174}$ Economic deprivation and racial isolation also impair the motivation and ability of many black children to succeed in school, with the result that many young blacks are not well equipped to overcome the effects of discrimination. See Fiss, supra note 97, at 239. Thus, the vicious circle widens.

${ }^{175}$ See note 99 supra.

Housing authorities' decisions that locate low income housing in areas of racial isolation also have a disproportionate impact because they reinforce residential racial isolation and its concomitant economic deprivation. Federal law now mandates that housing officials locate housing to improve racial balance. See Hills v. Gautreaux, 96 S. C. 1538, 1548-49 (1976). Therefore, as a practical matter, the issue of the applicability of DRI theory to site selection decisions is academic. Whether federal law governs land use decisions having a disproportionate racial impact, however, is uncertain. One commentator has ably argued that the fair housing provisions of the Civil Rights Act of 1964, tit. VIII, 42 U.S.C. $\$ \S 3601-3631$ (1970), should be construed as embodying a disproportionate impact test similar to that of Title VII. Comment, supra note 172 , at 150-74. The circuits are split on the issue whether impact or motive is the proper test under Tille VIII. Compare United States v. City of Black Jack, 508 F.2d 1179, 1184-85 (8th Cir. 1974), cert. denied, 95 S. Ct. 2656 (1975) (impact), with Boyd v. Lefrak Organization, 509 F.2d 1110, 1113-14 (2d Cir.), cert. denied, 96 S. Ct. 197 (1975) (motive). An exclusionary land use decision can effectively impede the implementation of national housing policy by preventing a federally-funded housing authority, or a private developer under contract with the United States Department of Housing and Urban Development, from locating low income housing in an area where it would improve racial balance. See Hills v. Gautreaux, 96 S. Ct. at 1550 (HUD's actions cannot "displace the rights and powers accorded local government entities under federal or state housing statutes or existing land use laws." (emphasis supplied)).

${ }^{176}$ Report of the United States National Advisory Commission on Civil DISORDERS (1968).

${ }^{177}$ See Comment, supra note 172, at 129-30:

The pervasiveness of segregated living patterns is starkly demonstrated by recent estimates that by the year 2000 the population of our cities will be approximately 75 percent black and 25 percent white, and that to achieve equal demographic dispersion of blacks and whites at present would require the relocation of some 80 to ninety percent of all blacks in the country.

In addition, minority city dwellers are often limited to housing which is over-priced and of substandard quality. Several studies have indicated, for example, that approximately two-thirds of all nonwhite families in central cities 
cause businesses are leaving the city too, residential racial isolation, as we have observed, contributes to black unemployment (and underemployment) and severe economic deprivation. ${ }^{\mathbf{1 7 8}}$ Moreover, racially isolated neighborhoods lead to racially imbalanced classrooms, where the deprivation and the familial and social disintegration often so apparent in the streets are frequently mirrored. ${ }^{179}$ To fail to apply DRI theory to exclusionary land use decisions is to fail to ask more than minimal justification for actions that grievously compound the legacy of slavery and discrimination. ${ }^{180}$

Application of DRI theory would not result in the invalidation of each and every land use decision having a disproportionate racial impact, but it certainly would minimize and moderate such decisions. How DRI theory would affect land use decisions is usefully illustrated by a case that the Supreme Court will review during the 1976 term, Metropolitan Housing Development Corp. $v$. Village of Arlington Heights. ${ }^{181}$ Metropolitan involved a constitutional challenge to a refusal by Arlington Heights to rezone a parcel of land to permit Metropolitan, a nonprofit corporation, to construct housing for persons of low and moderate income.

live in neighborhoods marked by substandard housing and that nonwhites in urban areas receive an average of 30 percent less value for their housing dollar because of their race. (footnotes omitted)

${ }^{178}$ This economic deprivation, because of the costs of social welfare programs and crime, disserves the economic well-being of the entire society. See Metropolitan Hous. Dev. Corp. v. Village of Arlington Heights, 517 F.2d 409, 414 n.2 (1975), quoted in text accompanying note 187 infra; TRB: Blacks and Whites, New Republic, Apr. 10, 1976, at 2.

${ }^{179}$ School busing is obviously a derivative issue: the real problem is residential racial isolation, without which there would be no need for school busing. See TRB: Blacks and Whites, supra note 178 .

${ }^{180}$ See note 174 supra \& accompanying text.

We ought not to overlook the glaring, sad fact that exclusionary land use decisions can effectively conceal a desire for racially "pure" communities. See note 104 supra. See also notes $99,107,175$ supra. The virulent motivation that for so long generated overt racial discrimination in housing has now, to some extent, been sublimated; but it has not disappeared, and it is either quixotic or dishonest for courts to act as if it had. This motivation has merely found more respectable outlets, such as exclusionary zoning policies. There is an intrinsic check on covert discrimination in employment: the desire to run a profitable business and so to hire the best, or cheapest, labor available, black or white. But no similar countervailing interest exists in the context of housing and land use policy. To permit, as a constitutional matter, land use decisions to frustrate the racial depolarization of American society, and to forbid only decisions whose "discriminatory purpose" is evidentiarily apparent, is to strike the shadow but yield the substance: "[C]lever men may easily conceal their motivations." United States v. City of Black Jack, 508 F.2d 1179, 1185 (8th Cir. 1974); see Comment, supra note 172, at 151-52.

${ }^{181} 517$ F.2d 409 (7th Cir.), cert. granted, 96 S. Ct. 560 (1975); see Note, Zoning -Equal Protection, 1976 Wisc. L. Rev. 234. 
The Seventh Circuit rejected Metropolitan's claim that the refusal was motivated by a discriminatory purpose. ${ }^{182}$ The court indicated that disproportionate racial impact-a greater percentage of blacks than whites would have qualified for the proposed housing-by itself, is not conclusive, ${ }^{183}$ acknowledging, in effect, that under DRI theory more factors must be weighed than the bare fact of disproportionate impact. In evaluating the constitutional adequacy of Arlington Heights' refusal to rezone, the court focused on the racial demography of the metropolitan region of which Arlington Heights is a part and on alternatives for supplying the needed housing while diminishing the residential racial isolation of the surrounding region. ${ }^{184}$

The population of Arlington Heights, a suburban township on the outskirts of Chicago, was 64,884 in 1970. Of this number, only twenty-seven were black. ${ }^{185}$ Moreover, as the court described it:

The four-township northwest Cook County area, of which Arlington Heights is a part, had a population increase from 1960 to 1970 of 219,000 people, but only 170 of these were black. Indeed, the percentage of blacks in this area actually decreased over this ten-year span while the percentage of the population in the entire Chicago metropolitan area that was black increased from fourteen percent to eighteen percent. ${ }^{186}$

The impact of [these statistics] can be fully appreciated only in the context of the shift in employment opportunities during that same period. While the City of Chicago lost 230,000 jobs, the number of jobs in the four-township Arlington Heights area rose from 100,000 to 200,000 . Blacks, however, have not been able to take full advantage of these job opportunities. In 1970 only 137 of the 13,000 people who worked in Arlington Heights were black. Part of the explanation for this is that many black workers have been unable to find housing they can afford in Arlington Heights. A

182517 F.2d at 412.

${ }^{183} I d$. at $412-13$.

${ }^{184}$ Metropolitan was to receive federal financing, and national housing policy mandates that sites for federally-assisted low income housing be selected for the purpose of improving racial balance. See note 175 supra.

${ }_{185} 517$ F.2d at 413-14.

${ }^{186} I d$. at 414 (footnote omitted). 
study issued by the Cook County Office of Economic Opportunity indicated that based on its survey almost all the black workers in Arlington Heights resided in Chicago. Moreover, the report stated that one of the main problems Arlington Heights' employers faced in hiring minorities was the lack of adequate housing within a reasonable distance of their plants. ${ }^{187}$

Given the extent of the surrounding racial isolation, the court next examined whether there were any alternatives for supplying the needed housing while diminishing the racial isolation, and it concluded that no "economically feasible and suitable" sites for low and moderate income housing, other than the one selected by Metropolitan, existed in Arlington Heights. ${ }^{188}$ The alternative of building the needed housing outside Arlington Heights, in an area of greater minority concentration, would have done nothing to diminish the racial isolation in Arlington Heights or in the greater Chicago area. ${ }^{189}$ In fine-tuning its balance, the court noted that Arlington Heights "has not sponsored nor participated in any low income housing developments, nor does the record reflect any such plans for the future."190 The Seventh Circuit's evaluation of the disproportionate impact of Arlington Heights' refusal to rezone was both thorough and balanced-an exemplary illustration of DRI theory applied to land use decisions. ${ }^{191}$ Although application of DRI theory to land use decisions will not always yield easy answers, the answer in Metropolitan was clear, and the court was correct: the refusal to rezone was unjustified. ${ }^{192}$

${ }^{187}$ Id. at 414 n.2.

${ }^{188}$ Id. at 414 .

${ }^{189}$ Presumably if there were a township in the vicinity of Arlington Heights with a higher percentage of white residents, locating the needed housing in that township would do more to diminish the racially imbalanced demography of the surrounding region than locating the housing in Arlington Heights. No such township existed. See id. at 414 n.1.

${ }^{190} I d$. at 414.

${ }^{191}$ Other cases have endorsed the application of disproportionate impact theory to land use decisions. See, e.g., Crow v. Brown, 457 F.2d 788, 790 (5th Cir. 1972); Gautreaux v. Romney, 448 F.2d 731, 738 (7th Cir. 1971) (dictum); Kennedy Park Homes Ass'n v. City of Lackawanna, 436 F.2d 108, 114 (2d Cir. 1970), cert. denied, 401 U.S. 1010 (1971); Alameda Spanish Speaking Organization v. Union City, 424 F.2d 291, 295-96 (9th Cir. 1970).

${ }^{192}$ The Court's decision in Metropolitan did not intrude seriously on Arlington Heights' fiscal or environmental interests. See 517 F.2d at 411 (referring to "studies showing that Lincoln Green [the proposed development] would not cause major traffic problems and would make a net contribution to the Village in terms of taxes"); $i d$. at 415: 
A decision by the Supreme Court rejecting the disproportionate impact theory of racial discrimination in the context of land use decisions like that challenged in Metropolitan would effectively constitute a declaration that, notwithstanding the collective societal responsibility for the racial isolation and the especially severe economic deprivation of black Americans, and notwithstanding the consequences of that isolation, including diminished employment opportunities and inferior schooling, a municipality has virtually unbounded discretion under the fourteenth amendment, no matter what the surrounding circumstances might be, to make land use decisions exacerbating the racial isolation and economic deprivation of blacks in America. ${ }^{193}$ Whatever the verbiage in which it is packaged, that declaration is ethically barren and, as a matter of equal protection theory, sorely deficient. ${ }^{194}$

Lincoln Green will not be a high-rise development, but merely a cluster of two-story townhouses no higher than the surrounding single family homes. As noted by two dissenting members of the Arlington Heights Plan Commission, in terms of density, architecture and most other characteristics, such townhouses are more similar to [single family] dwellings than to [multi-family] buildings. The planning rationale behind the buffer zone policy has only minimal applicability to this type of low-rise, open-space development.

Note that Metropolitan involved a challenge to a refusal to rezone a particular parcel . of land. Such challenges, because narrowly focused, are much more manageable for the judiciary than are challenges to municipal zoning schemes in toto. See Note, The Inadequacy of Judicial Remedies in Cases of Exclusionary Zoning, 74 Mich. L. Rev. 760, 760 n.4 (1976).

${ }^{193}$ After all, virtually any land use decision will satisfy minimal scrutiny because it will be rationally related to a legitimate, typically environmental, objective.

In James v. Valtierra, 402 U.S. 137 (1971), the Supreme Court upheld over an equal protection challenge a California constitutional provision requiring that no federally- or state-assisted low income housing development could be located in a community unless the development were approved by that community in a referendum. The Court in Valtierra did not address directly the issue of disproportionate racial impact, but, in Washington v. Davis, the Court cited Valierra as support for rejecting DRI theory. $96 \mathrm{~S}$. Ct. at 2048 . DRI theory would not have helped the plaintiffs in Valtierra, because their challenge was directed at the referendum provision in abstracto and not at a particular referendum allegedly having a disproportionate racial impact. The disproportionate impact theory applies to challenges to specific decisions, as in Metropolitan, or practices, as in Washington, enabling a court to determine if the specific decision or practice has a disproportionate racial impact. A facially neutral referendum provision, like that challenged in Valtierra, has no impact. Only particular referenda pursuant to the provision have impact, and whether a particular referendum has an impact that cannot be justified depends on the particular circumstances involved. Thus, Valtierra is not authority for rejecting DRI theory in the context of particular land use decisions.

${ }^{194}$ To the extent the Supreme Court is willing to concede to Congress the power, under the fourteenth amendment, to apply a disproportionate impact test to state and local land use and housing policies-perhaps Congress has already done this, see note 175 supra-a ruling by the Supreme Court in Metropolitan that the equal protection clause contemplates only motivational modes of racial discrimination would encounter the problem discussed in note 148 supra. 


\section{Conclusion: A Question of Judicial Role}

In Washington v. Davis, the Supreme Court failed to come to grips with the very theory it rejected. The Court failed to understand that the disproportionate impact theory of racial discrimination has a limited jurisdiction-that the theory, if accepted, would not govern, for example, jury selection or legislative districting. The Court also failed to understand that in the contexts in which it would apply, the theory contemplates a flexible standard of review, requiring more of government than minimal rationality, but less than the strict justification demanded when the government has employed race or its functional equivalent as a criterion of selection. Moreover, the Court made no effort to isolate and to evaluate the underlying premises of DRI theory, especially the collective moral responsibility of American society for the legacy of slavery and racial discrimination that is the underlying cause of disproportionate racial impact.

To some extent the issue whether DRI theory-a constitutional theory of equal protection-should be accepted has been mooted by legislation. For example, Title VII now subjects hiring and promotion practices in public employment to a disproportionate impact test. ${ }^{195}$ And Title VIII has been construed by at least one federal court of appeals to subject exclusionary land use practices to a disproportionate impact test. ${ }^{196}$ Nonetheless, the integrity of DRI theory as constitutional doctrine is independent of mooting legislation, and the theory merits close examination for that reason alone. ${ }^{197}$

After DRI theory is better understood, what will likely separate those who endorse the theory from those who reject it is a conception of judicial function. Under DRI theory, a court is called upon to balance the interests of racial minorities against the interests reflected by the laws or practices in issue. The underlying notion is not that courts singlehandedly can remedy the ills afflicting the legatees of slavery and racial oppression, but that the courts can require agencies of government to attend to the interests of racial minorities with greater sensitivity.

195 See note 149 supra.

${ }^{196}$ United States v. City of Black Jack, 508 F.2d 1179 (8th Cir. 1974).

${ }^{197}$ Moreover, the integrity of a disproportionate racial impact theory in the constitutional context is plainly relevant to the integrity of the theory in a statutory context because the underlying premises and considerations are similar in both contexts. In fact, the legitimacy of adopting a statutory disproportionate impact test may depend on whether the Constitution is construed to embody such a test. See note 148 supra. 
Legislatures and other government agencies are not as sensitive to the interests of racial minorities as to majoritarian interests. ${ }^{198}$ Occasionally, a legislature will overlook less intrusive ways of advancing its objectives and, instead, will infringe thoughtlessly and needlessly on the interests of racial minorities. As Judge Wright observed, "the arbitrary quality of thoughtlessness can be as disastrous and unfair to private rights and public interest as the perversity of a willful scheme." ${ }^{199}$ One important, even basic, function of the judiciary in American government, in constitutional cases, is to guard against thoughtless legislative inattention to even the legitimate interests of those "discrete and insular" minorities whose political voice is not always sufficiently audible. ${ }^{200}$ It is difficult to discern any sound reason why the judiciary should abdicate that salutary function, in the exercise of which courts have made what is surely an estimable contribution to the ethical character of American politics and government. Surely that function is no less important because inevitably limited in its impact.

On September 6, 1976, Time Magazine reported:

Armed with shotguns, Magnums, carbines and clubs, teams of men sweep the streets enforcing a 10 p.m. to 6 a.m. curfew for everyone under 18. Citizens cower behind the barricaded doors of their own homes, listening to the shots and shouts that punctuate the night air. The city is not Beirut or Belfast but Detroit, whose agonies are every bit as real and whose conflicts seem equally impossible to eradicate.

After weeks of gang terrorism that included killings, a near riot, robberies, pillaging and rape, Detroit's black mayor, Coleman Young, belatedly rushed back

${ }^{198}$ See Hobson v. Hansen, 269 F. Supp. 507-08 (D.D.C. 1967), aff'd sub nom. Smuck v. Hobson, 408 F.2d 175 (D.C. Cir. 1969):

Judicial deference to [legislative] judgments is predicated in the confidence courts have that they are just resolutions of conflicting interests. This confidence is often misplaced when the vital interests of the poor and of racial minorities are involved. For these groups are not always assured of a full and fair hearing through the ordinary political processes, not so much because of the chance of outright bias, but because of the abiding danger that the power structure-a term which need carry no disparaging or abusive overtones-may incline to pay little heed to even the deserving interests of a politically voiceless and invisible minority.

${ }^{199} \mathrm{Id}$. at 497.

${ }^{200}$ See United States v. Carolene Prods. Co., 304 U.S. 144, 152-53 n.4 (1938); Chayes, The Role of the Judge in Public Law Litigation, 89 HARv. L. Rev. 1281, 1311, 1315 (1976). 
from vacation and vowed last week, "We will not tolerate lawlessness in the streets. We will stand for it no longer." ...

... [T]he malaise that grips the decaying motor capital is unlikely to yield to short-term measures like a curfew-and even less to mere rhetoric and good intentions. As John Cardinal Dearden, the Archbishop of Detroit, put it last week, "We are called upon to rebuild the structure."

The problems that plague Detroit (pop. 1.4 million) differ only in magnitude from those that afflect other large cities in the U.S.: an eroding tax base as affluent whites abandon the core city; reduced services, including police protection; widespread unemployment, particularly among black youths; neighborhoods where housing and other buildings have been allowed to deteriorate; and low-quality schools. Perhaps more debilitating than any of these is a growing feeling that nothing will —or can—be done to reverse the trend. ${ }^{201}$

Whether anything can or will be done to reverse the trend is an open question. The courts can play a role in answering that question. The most troubling aspect of Washington $v$. Davis is not that the Court's opinion was deficient analytically but that the Court seemed to say that the judiciary shall play a severely diminished role in ameliorating racial inequities.

Questions concerning the proper relationship between the judiciary and nonjudicial agencies of government-between legislative will and judicial limit-are perennial and inexhaustible. Such questions rarely have one "right" answer. ${ }^{202}$ In this respect, it is really not possible to say that the Supreme Court's rejection of DRI theory-and its implicit rejection of the judicial role contemplated by the theory-was "wrong." Whatever one's position with respect to the issue of judicial role, however, surely it is perplexing that the Court in Washington v. Davis gave virtually no evidence of an effort to comprehend and evaluate the theory it rejected. Given the importance of the issues involved,

${ }^{211}$ A Long, Hot Summer for Detroit, Time, Sept. 6, 1976, at 16.

${ }^{212}$ Compare Bork, Neutral Principles and Some First Amendment Problems, 47 IND. L.J. 1, 1-20 (1971), and Rehnquist, The Notion of a Living Constitution, 54 TEx. L. Rev. 693 (1976), with A. Cox, The Role of the Supreme Court in American Government (1976), and Perry, Abortion, the Public Morals, and the Police Power: The Ethical Function of Substantive Due Process, 23 U.C.L.A.L. Rev. 689, 707-22 (1976). 
the Court's performance was especially lamentable. During the 1976 term, the Court will again have occasion to consider disproportionate impact theory. ${ }^{203}$ The Court would do well to give the theory a fuller airing.*

${ }^{203}$ See Metropolitan Hous. Dev. Corp. v. Village of Arlington Heights, 517 F.2d 409 (7th Cir.), cert. granted, 96 S. Ct. 560 (1975), discussed in notes 181-92 supra \& accompanying text.

* On Jan. 11, 1977-after this Article went to press-the Supreme Court decided Village of Arlington Heights v. Metropolitan Hous. Dev. Corp., 45 U.S.L.W. 4073 (U.S. Jan. 11, 1977), reaffirming the principle of Washington v. Davis, 96 S. Ct. 2040 (1976), that a showing of discriminatory purpose is necessary to make out a claim of racial discrimination under the equal protection clause. 45 U.S.L.W. at 4077 . The Court reversed the Seventh Circuit's judgment and remanded the case for consideration of the claim that the challenged zoning decision violated the Fair Housing Act, 42 U.S.C. $\$ \$ 3601-3631$ (1970). 45 U.S.L.W. at 4078-79; see note 175 supra. The Court's decision - even its failure to reexamine the reasoning of Washington-came as no surprise; in Washington, the Court indicated its disapproval of the Seventh Circuit's Arlington Heights decision in a footnote. $96 \mathrm{~S}$. Ct. at $2050 \mathrm{n} .12$. What was surprising, however, was that both Justice Marshall and Justice Brennan joined in the reaffirmance of the Washington principle, a principle that neither Justice had found necessary to address in Washington. See id. at $2056 \mathrm{n}$.1. One would have thought that Justice Marshall's dissenting opinion in San Antonio Independent School Dist. v. Rodriguez, 411 U.S. 1, 70 (1973), would have led him in Arlington Heights to demand a scrutiny of the zoning decision stricter than the relaxed, "rational basis" scrutiny authorized by Washington. Cf. Brennan, State Constitutions and the Protection of Individual Rights, 90 HARv. L. REv. 489, 501 (1977) (suggesting admiration for the New Jersey Supreme Court's decision in Southern Burlington County NAACP v. Township of Mt. Laurel, 67 N.J. 151, 336 A.2d 713, appeal dismissed $\mathcal{E}^{\circ}$ cert. denied, 423 U.S. 808 (1975) (invalidating town's exclusionary zoning ordinance on basis of state constitution's due process clause)).

Doubtless Arlington Heights will be a source of much commentary. Even the popular press has taken notice. Compare Will, Common Sense on Race, Newsweek, Jan. 24, 1977, at 80, with Wicker, Tightening the Ring, N.Y. Times, Jan. 30, 1977, § 4, at 17, col. 5. One of the most interesting facets of the decision is its implicit overruling of Palmer $\%$. Thompson, 403 U.S. 217 (1971). In Palmer, the Court ruled that a law or practice plausibly related to a discriminatory objective but, nonetheless, rationally related to a legitimate, nondiscriminatory objective as well would be upheld and that an inquiry into motivation would not be undertaken. See text accompanying notes 36-40 \& 47-49 supra. In Arlington Heights, however, the Court ruled that "proof that a discriminatory purpose has been a motivating factor in the [challenged] decision," 45 U.S.L.W. at 4077 , shifts to the defender of the decision "the burden of establishing that the same decision would have resulted even had the impermissible purpose not been considered," id. at $4078 \mathrm{n} .21$. But the Court's novel readiness to engage in motivational inquiry even when a law or practice is rationally related to a legitimate objective is without much practical significance. After all, it would be a rare case indeed in which the defender of a decision could not make the required showing-unless, perhaps, his burden of proof on the issue is severe. Thus, the implicit overruling of Palmer-plainly an attempt by the Court to diminish the possibility that municipalities will "take advantage" of the Arlington Heights decision -seems more apparent than real. 